\title{
Effects of seismic activity on groundwater level and geothermal systems in İzmir, Western Anatolia, Turkey: the case study from October 30, 2020 Samos Earthquake
}

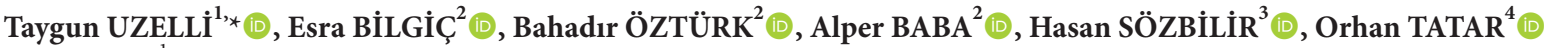 \\ ${ }^{1}$ İzmir Institute of Technology, Geothermal Energy Research and Application Center, İzmir, Turkey \\ ${ }^{2}$ İzmir Institute of Technology, Engineering Faculty, Department of International Water Resources, İzmir, Turkey \\ ${ }^{3}$ Dokuz Eylül University, Earthquake Research and Application Center, İzmir, Turkey \\ ${ }^{4}$ Department of Geological Engineering, Faculty of Engineering, Sivas Cumhuriyet University, Sivas, Turkey
}

\begin{abstract}
\begin{tabular}{llll}
\hline Received: $12.01 .2021 \quad \bullet \quad$ Accepted/Published Online: $14.09 .2021 \quad \bullet \quad$ Final Version: 30.10 .2021 \\
\hline
\end{tabular}
Abstract: The October 30, 2020 Samos earthquake (Mw 6.6) affected the Aegean Sea and environs, caused destruction and loss of life in the city of İzmir located $70 \mathrm{~km}$ away from the earthquake epicenter. Before this earthquake, water resources were monitored in the areas of Bayraklı, Gülbahçe, and Seferihisar. For this purpose, 10 groundwater monitoring wells were drilled in the Bayraklı area, where groundwater level, temperature, and electrical conductivity changes were monitored at 1-h intervals in 5 wells. Besides physical parameters such as groundwater levels, temperatures and electrical conductivities, hydrogeochemical cations, and anions measured in the study area. Change in the groundwater levels was observed before, during, and after the Samos earthquake. A trend of rising groundwater level was observed two days before the mainshock, to a height of $10 \mathrm{~cm}$, and the level was maintained till the end of the earthquake. The water levels returned to its original height after about 7 to 10 days of the earthquake. Moreover, electrical conductivity (EC) values were changed because of the interaction with the surrounding rocks and well walls, mixing with different waters during the earthquake shaking. The essential anomalies were observed in the geothermal fields of Gülbahçe and Seferihisar. Due to this earthquake, new geothermal springs emerged along the NE-SW trending Gülbahçe and Tuzla faults, located about 50 to $20 \mathrm{~km}$ from the Samos earthquake epicenter, respectively. The new geothermal waters are in $\mathrm{Na}-\mathrm{Cl}$ composition and similar to other geothermal springs in the region. While the recorded water temperatures in the new geothermal springs vary from 40 to $45^{\circ} \mathrm{C}$ in Seferihisar, it was measured between 35 and $40^{\circ} \mathrm{C}$ in Gülbahçe. Due to these anomalies, it is found essential to monitor the effect of the earthquake on the physical and chemical characteristics of the groundwater and its usefulness in earthquake predictions.
\end{abstract}

Key words: Groundwater monitoring, Samos earthquake, Bayrakl1-İzmir, geothermal field.

\section{Introduction}

Seismic disturbances can cause damages to the earth's crust and affect the physical and chemical characteristics of groundwaters and geothermal waters. Nowadays, a great number of researchers try to put forward the relationship between earthquakes, groundwater levels, and chemistry in different situations by field observations and scientific studies especially (Wang et al., 2001; Sneed et al., 2003; Kitagawa et al., 2006; La Vigna et al., 2012; Shi and Wang, 2014; Manga and Wang, 2015; He and Singh, 2019; Lee et al., 2020; Senthilkumar et al., 2020). Effects of the earthquakes on groundwater response vary under the control of the aquifer with the factors such as lithology, hydrogeochemistry, permeability, porosity, pore pressure change, aquifer type, barometric pressure, tidal effects, fault zones, well properties, and earthquake characteristics (Bredehoeft, 1967; Roeloffs, 1988; Brodsky

* Correspondence: taygunuzelli@iyte.edu.tr et al., 2003; Claesson et al., 2004; Falcone et al., 2012; Shi et al., 2015; Rutter et al., 2016; Yan et al., 2016; Liu et al., 2018; Petitta et al., 2018; Shih, 2018; Sun et al., 2019; Lee et al., 2020; Senthilkumar et al., 2020). When the waterrock interactions occurring in the groundwater aquifer system are examined, opened/closed cracks and fault planes, deformation by co-seismic strain and post-seismic hydrogeological conditions can be considered as primary controllers (Pasvanoglu et al., 2004; Charmoille et al., 2005; Skelton et al., 2008; Reddy et al., 2011; Woith et al., 2013; Skelton et al., 2014). In previous studies, researches and observations on earthquake and water-rock interaction were also mostly related to liquefaction (Wang et al., 2001), change of groundwater level in wells (Roeloffs et al., 2011; Chen et al., 2013; Lee et al., 2020), and change of water chemistry (Rosen et al., 2018; Kaown et al., 2019; Kim et al., 2019). 
Rosen et al. (2018) grouped the changes that may occur after an earthquake in fractured carbonate aquifers. In the grouping methodology, pre-earthquake changes in physical, chemical, and isotopic properties, different events with mechanisms affecting the post-earthquake water quality are taken as a basis. As in the classification within the scope of the study conducted by Rosen et al. (2018), many studies were conducted on these topics in the literature, and significant findings were obtained. Post-earthquake events include strain/rupture of faults (Cotecchia et al., 1990; Yan et al., 2016; Petitta et al., 2018), near-surface deformations (Pasvanoglu et al., 2004; Charmoille et al., 2005), dilation and mixing of different aquifers (Poitrasson et al., 1999), the release of geothermal waters (Barberio et al., 2017) and gases (Favara et al., 2001; Chiodini et al., 2004; Italiano et al., 2004; Ciarletti et al., 2016).

The purpose of this study was to examine the effect of the Samos earthquake swarm on October 30, 2020 on groundwaters and geothermal systems. Observations made within the scope of this study are mostly based on the relationships between earthquakes and water level changes, differences in geothermal activity, and water chemistry. For this reason, 10 groundwater monitoring wells were installed in the alluvial plain of the Bayraklı region to assess responses in groundwater level. In geothermal fields, which were monitored continuously for a long time, physical and hydrogeochemical water parameters were examined, and the earthquake effects were tried to be determined. As a result of the studies carried out, some obvious effect-response situations have been revealed.

\subsection{Study area}

Before and after the Samos earthquake sequence in the İzmir region, this study provides a valuable observation dataset for physical and hydrogeochemical responses at groundwater and geothermal systems.

The mainshock of the earthquake (Mw 6.6-Republic of Turkey Ministry of Interior Disaster and Emergency Management Presidency (AFAD); Mw 7.0-The United States Geological Survey (USGS)) occurred in the Aegean Sea, north of the Samos Island, southwest of İzmir, at 14:51 local time on October 30, 2020. According to the preliminary earthquake report of the Earthquake Research and Application Center of Dokuz Eylül University (Sözbilir et al., 2020), the earthquake occurred with the rupture of the North Samos Fault, which has a normal fault character with E-W extension, and aftershocks occurred in the regions between NW and NE of the fault. According to the USGS (The United States Geological Survey), the estimated peak ground acceleration reached $0.4 \mathrm{~g}$ value, and shake intensity (according to the Modified Mercalli scale of Worden et al., 2012) was between VII and VIII (Figures 1a and $1 \mathrm{~b}$ ).
Within the scope of this study, earthquake data of the AFAD (Figure 1b) between the dates 24.10.2020 and 22.11.2020 were used. In the geographical area between latitudes 37.4790-38.8475 and longitudes 25.613527.9973 , a total of 4334 earthquake data were recorded, and 353 earthquakes were higher than a magnitude of 3 .

The study area is located in the province capital of İzmir includes many active fault segments (Figure 1c). The geothermal field of Gülbahçe $(50 \mathrm{~km}$ away from epicenter), the geothermal field of Seferihisar (20 km away from epicenter), and the district of Bayraklı $(70 \mathrm{~km}$ away from the epicenter) are located in the north of the city of Neon Karlovasion-Samos Island. Although there is a long distance to the earthquake epicenter, quite remarkable findings were obtained in terms of both earthquake damages and groundwater responses.

\section{Geological framework}

\subsection{Tectonic setting}

The city of İzmir, Turkey's third-largest city in terms of population density, is in the coastal part of Western Anatolia. İzmir is located in a seismically active region, defined as the "Mediterranean Earthquake Belt" as well, which is currently under the influence of the back-arc extension related to the collision of African and Eurasian plates (Bozkurt, 2001).

The dominant morphology in Western Anatolia is shaped by basin and range type extension. The Gediz, Büyük Menderes, and Küçük Menderes basins are the most important depressions in the region, bounded by the E-W trending normal fault systems. Southwest of the Gediz graben is the inner bay of İzmir and the terrestrial part of it is called the Bornova depression where the severe destruction and the loss of life occurred. The Bornova depression, bounded by İzmir Fault from the south and by the Bornova-Karşyaka Fault from the north, is filled with Holocene alluvial deposits unconformably overlying Miocene volcano-sedimentary succession (Uzel et al., 2012). These units overlie the basement rocks of the Paleozoic Menderes Massif, the Mesozoic Karaburun Platform carbonates, and the Late Cretaceous-Paleocene Bornova Flysch Zone.

The NE-SW trending strike-slip faults such as Tuzla Fault and Seferihisar Fault control the tectonic activity in the region as well as the geothermal waters. Here deepseated fault planes are the most important structural controls that allow meteoric waters to infiltrate deeper levels and which ascend to the surface after heating. The Seferihisar geothermal area is currently under the influence of the NE-SW trending Tuzla Fault Zone (Emre and Barka, 2000; Emre et al., 2005; Uzel and Sözbilir, 2008). Cumalı, Doğanbey, and Karakoç geothermal fields are areas under the control of this fault zone. The same fracture and fault 


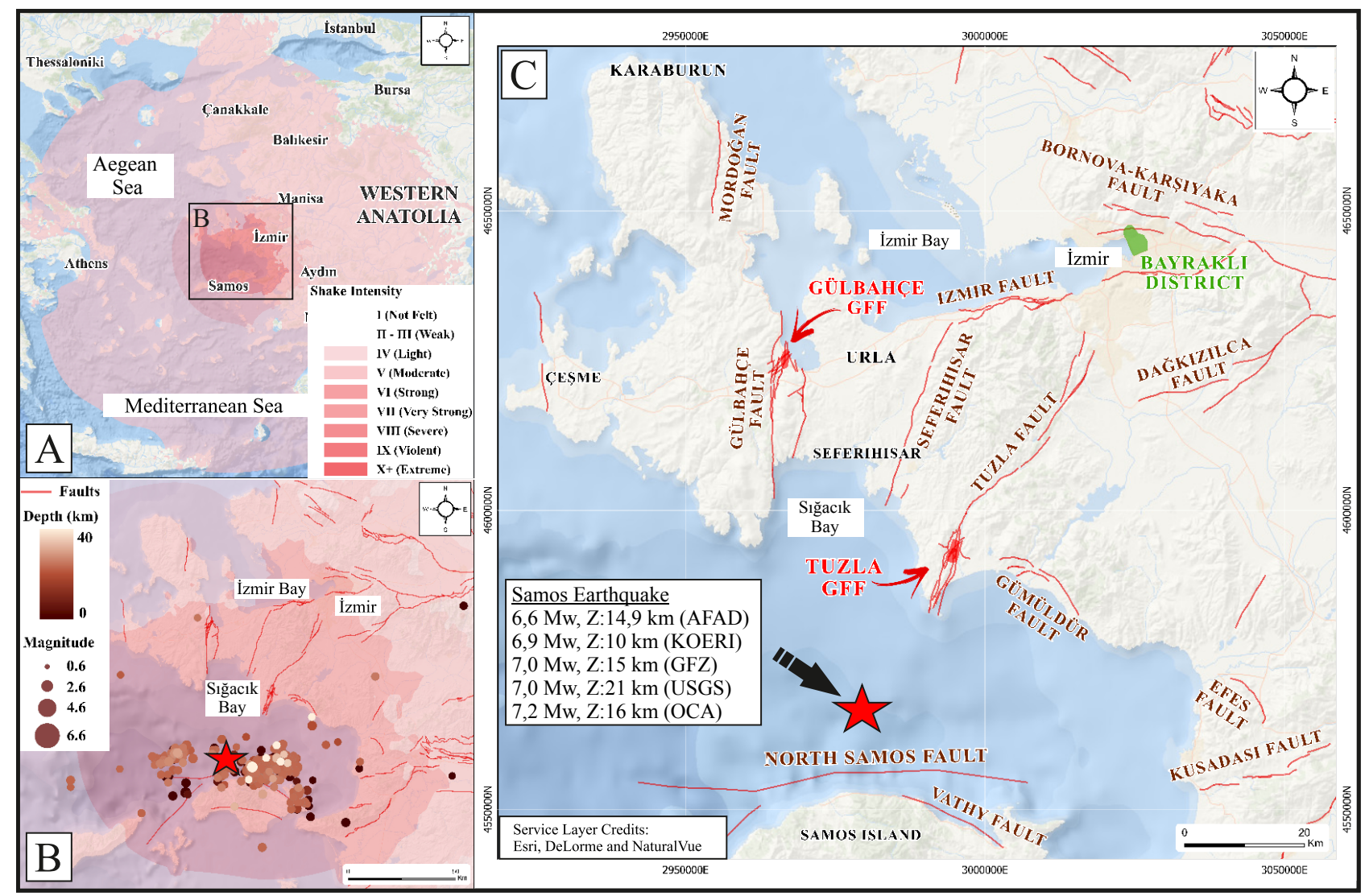

Figure 1. a) The shake intensity map of the Samos earthquake, b) aftershocks greater than Mw 3.5 during the Samos earthquake swarm, c) location map of the study area with earthquake mainshock data and active faults (active faults digitized from Emre et al., 2013).

segments may cause seawater intrusions to the geothermal waters in the area close to the Aegean Sea.

Another structural element is the Gülbahçe Fault Zone, and segments of the zone play an important role in the formation of the Gülbahçe geothermal field (Erdoğan, 1990; Emre et al., 2005; Sözbilir et al., 2009). The Gülbahçe Fault Zone consists of N-S trending fault segments that cause a connection between the geothermal system and seawaters in the Gülbahçe Bay (Uzelli et al., 2017). South of these faults is the seismogenic source of the Samos earthquake, the North Samos Fault, limiting the depression area deeper than $1000 \mathrm{~m}$ (Pavlides et al., 2009; Chatzipetros et al., 2013). Seismic data indicate that a 37-km-long rupture occurred during the earthquake with a maximum slip of $1.8 \mathrm{~m}$ (Ganas et al., 2020).

Within the scope of this study, Gülbahçe and Tuzla faults, which are among the faults that can produce destructive earthquakes in the vicinity of İzmir, were investigated in terms of geothermal activity.

\subsection{Hydrogeological setting}

Being in the Mediterranean climate zone (Csa typeKöppen-Geiger), İzmir has hot and dry summers and mild and rainy winters. The effect of geographical features on the climate is relatively high in İzmir as well as in the Aegean Region. According to the General Directorate of Meteorology data, July and August are the hottest and January and February are the coldest months. The annual average temperature varies between 14 and $18{ }^{\circ} \mathrm{C}$ in the coastal areas. The average annual precipitation in İzmir is $700 \mathrm{~mm}$. More than $50 \%$ of the annual precipitation falls in winter, $40 \%-45 \%$ in spring and autumn, and $2 \%-4 \%$ in summer. This study was conducted during a long dry period.

The hydrogeological systems in Western Anatolia are under the control of permeable units and major tectonic elements. The fault and fracture systems provided secondary permeability and porosity and created suitable circulation channels in reservoir systems for both groundwaters and geothermal waters.

Generally, geothermal sites in the region can be observed in places with uprising geothermal waters along with the fault segments. The tectonic activity allows the mixing process of waters and shapes the hydrogeological system in the Gülbahçe and Seferihisar area. Detailed conceptual geothermal models of these geothermal fields have been mentioned in previous studies (Eşder and Şimşek, 1975; 
Uzelli et al., 2017). In the geothermal systems of the study area, the impermeable cover rocks cause the geothermal waters to form a geothermal reservoir, while the alluvial basin fillings in the Bayraklı field have unconfined and locally perched aquifers. There are shallow alluvial aquifers with near-surface groundwater levels between the İzmir Bay and Bayraklı-Bornova Plain (Baba and Yazdani, 2017). The site is characterized by water flow from the alluvium to the near-surface aquifer, as in similar local basins in the region. The study area was examined under three different regions in terms of hydrogeological properties.

\subsubsection{Seferihisar region}

The Seferihisar region is geographically located in Western Anatolia and has been explored from a geothermal point of views since 1970 (Eşder and Şimşek, 1975; Eşder, 1990). It is possible to examine the rock units forming the geothermal system in two main groups. Basement rocks (Paleozoic-Mesozoic metamorphic rocks of Menderes Massif and Upper Cretaceous-Paleocene Bornova Mélange) and cover units (Neogene and modern basin-fill units). Intercalations of sandstone-shale-conglomerates, serpentinites, and submarine volcanic of the Bornova Mélange have widespread outcrops in the study area.

The deformed basement flysch units along the Tuzla Fault Zone at the site are generally impermeable but support surface recharge along with the fault segments and fracture systems. In this way, the geothermal system reservoir located at a deeper level can contain sufficient geothermal water. For this reason, there is a fault-fracture controlled system rather than a geothermal system with a classical cover rock. Thus, intensely fractured basement rocks along the Tuzla Fault are the main reservoir of the Seferihisar geothermal system.

\subsubsection{Gülbahçe region}

The rock sequence exposed in the Gülbahçe area is divided into two main groups: the basement and cover rocks. The basement is made up of Triassic to Jurassic limestones and dolomites. The overlying cover rocks are Miocene volcano-sedimentary series and Quaternary deposits, and, because they are impermeable, they have formed confined aquifers in local basins.

Triassic and Jurassic karstic limestones and dolomites are important reservoirs around Gülbahçe. Basement rocks that outcrop in the geothermal field are bounded by the segments of the Gülbahçe Fault Zone (GFZ). Secondary permeability in limestones and dolomites provides surface recharge along with fault and fracture systems.

Previous studies show that deep flows occur in the basement and ascending geothermal waters are trapped and confined by semi/non-permeable Miocene volcanosedimentary units (Baba, 2011; Baba, 2013). However, geothermal waters move up along N-S trending GFZ fault segments, which are the primary structural control mechanisms of the geothermal activity in the region (Uzelli et al., 2017). Similarly, the formation of cold-water resources (e.g., the Malgaca-İçmeler Spring) in the region is provided through structural controls in limestones and volcanics. There are also springs and wells on the shorelines that have been affected by seawater intrusion. This shows that the aquifers in the region are in contact with each other and with seawater due to structural controls. After the Samos earthquake, no obvious physical or chemical changes were observed in these cold springs and wells.

\subsubsection{Bayraklı region}

The basement units around Bayraklı Plain consist of karstic limestones and flysch units. The Upper Cretaceous to Paleocene Bornova Mélange (Flysch) comprises limestone blocks, cherts, submarine volcanics, and serpentinites. Mesozoic limestones are the karstic aquifer of the system and are located in the deep levels of Bayraklı Plain, especially in the south and east.

The Miocene conglomerate, limestone, and sandstone sequence has porosity and permeability despite tuff and clay layers contained in the sequence. The overlying Miocene calc-alkaline volcanic products are lavas, pyroclastic rocks, dikes, and domes. These volcanic rocks are also important for the fractures, allowing meteoric surface water infiltration through the reservoir.

The groundwater level varies between 1 and $65 \mathrm{~m}$, and groundwater flows from east to west in Bayraklı Plain. According to the observations in the wells (Figure 2) drilled in this study, the closeness of the groundwater level to the surface allowed the unsaturated zone to remain at very shallow depths. It shows that it is an unconfined aquifer, except for the volcanic and deeply located basement unit aquifers around Bayraklı.

The shallow unconfined aquifers in the study area are composed of Tertiary and Quaternary alluvial deposits shed from the higher topography. The basin-fill is composed of alluvial fans, river deposits, and coastal deposits.

\section{Material and methods}

Before the occurrence of Samos earthquake, 10 observation wells were drilled in the area of Bayraklı (Figure 2). Field observations were made at least once a week between October 30 and November 24, 2020 while water sampling was performed from all fields on November 22, 2020.

Three types of VanEssen branded groundwater diver data loggers were used in 5 of the observation wells (Figure 2d). The divers can take autonomous measurements with the desired time intervals, and hourly measurements were set for all the divers. TDDiver was located in four of the observation wells, and Baro-Diver and CTD-Diver were located in one well. TD-Divers and CTD-Diver record temperature and 


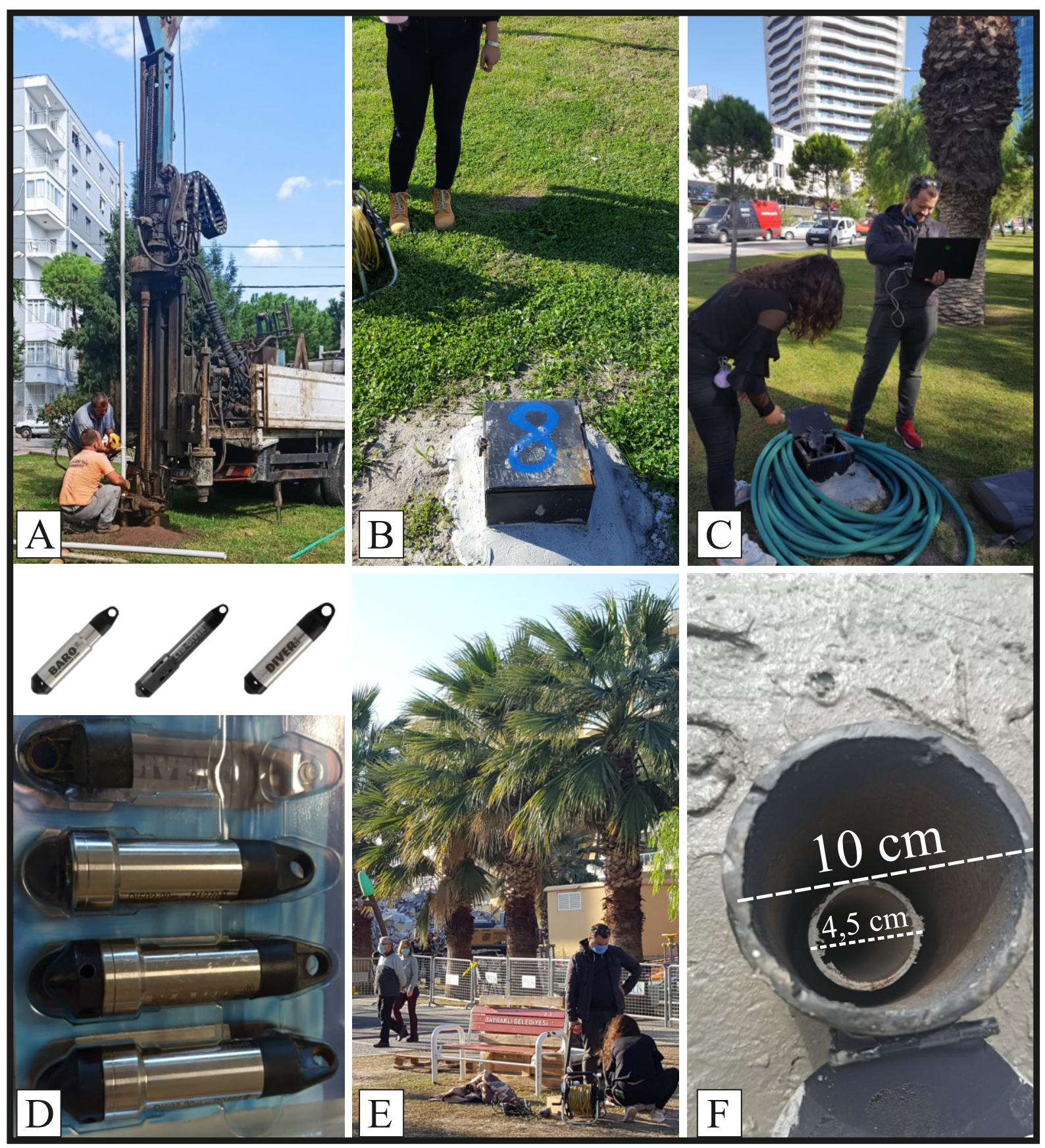

Figure 2. Photos of a) drilling phase, b) final state of the wells c) diver measurement stage, d) divers, e) measurement studies near collapsed buildings after the earthquake, f) well diameter features.

equivalent hydrostatic pressure of the water above the pressure sensor diaphragm to calculate the groundwater level with respect to ground level. Both logger types have an accuracy of $\pm 0.1^{\circ} \mathrm{C}$ in temperature and $\pm 0.5 \mathrm{~cm}$ $\mathrm{H}_{2} \mathrm{O}$ in pressure. In addition to TD-Divers, CTD-Diver is equipped with a four-electrode conductivity sensor that measures electrical conductivity with an accuracy of $\pm 1 \%$ of reading. Baro-Diver was used to determine the barometric pressure, which is also a required parameter for calculating the groundwater level.

Groundwater level and temperature measurements were performed from wells S1, S3, S6, S7, and S9, while electrical conductivity and barometric pressure measurements were observed from S9 well. Besides, electrical conductivity (EC), pH value, groundwater level, and temperature measurements were performed with field 
techniques from 10 wells in different periods and subjected to correlation with diver data.

The samples of groundwaters and geothermal waters were collected in bottles (LPDE) and analyzed by the Environmental Development, Application and Research Center within the İzmir Institute of Technology (IZTECH). Ion chromatography (IC) is used for the analysis of both anions and cations in water samples. Silica analysis was realized by using the Silicamolybdate method in the Geothermal Energy Research and Application Center within the İzmir Institute of Technology. Other physical parameter measurements of waters were carried out in the field by using multiparameter equipment.

\section{Results and discussions}

\subsection{Groundwater level changes in the area of Bayraklı}

In Bayrakll, buildings on Holocene alluvial deposits saturated with groundwaters were seriously affected after the Samos earthquake, and 17 buildings collapsed. Moreover, severe damages and casualties occurred in the area. The same area was also affected by destructive earthquakes during historic times. One of Izmir's old city settlements was in Bayrakll, called Smyrna, in the 7th century B.C. This settlement is completely abandoned around 300 B.C. However, the Bayraklı area from today has become a residential area of multi-storey buildings, business centers, and skyscrapers. According to researchers, the groundwater recharge from precipitation was about $27 \%$ in 1925 , but this amount dropped to 13\% in 2012 (Baba and Yazdani, 2017). This situation resulted from a reduction of groundwater recharge with urbanization because of the increase in impervious cover and increased stress on ground layers radically.

Figure 3 shows the location of the observation wells in the area of Bayrakll. Figure 3 also includes historical shoreline changes and the older riverbeds, which are projected from, the older map of Smyrna (Jones, 1939). The current Bayraklı map shows that the buildings are located on the Quaternary alluvium deposits, sea reclamation areas, old flood plain, and collapsed buildings are very close to the old river beds. Old river deposits are located on the floors of the buildings and can cause engineering soil problems although some parts of these river beds are transported to the sea via water channels.

There are deformed and fractured volcanic units in the north of the area. These units are cut and displaced by extensional faults forming the Bornova depression with $50 \mathrm{~m}$ to $300 \mathrm{~m}$ deep alluvial Bayraklı Plain (Baba and Yazdani, 2017). As a result of secondary permeability and alteration, surface recharge is provided along the slopes of the Yamanlar Mountain. The groundwater level is very close to the surface because the drainage area is very large, and different streams feed almost the entire plain. For this reason, the unconfined aquifer near the surface is the most important groundwater source in the region. However, clayey and impermeable units in places are proof that perched aquifers may also form in the hydrogeological system. The unscaled hydrogeological section shown in Figure 4 was created by interpolating the geological sections with shallow well data. According to the model, Bayraklı Plain, which is also located on the İzmir Bay coast, has an important hydrogeological system with its thick alluvial fill, surface recharge, and groundwater level near the surface. These hydrogeological features of Bayrakl Plain caused significant engineering problems during and after the Samos earthquake.

After the first mainshock on October 30, 2020, a seismic sequence totaled over $144(M>3.5)$ earthquakes (AFAD data) occurred around the Samos Island and İzmir region between October 24 and November 22, 2020. Figure 5 shows the magnitude-time and depthtime distribution of the seismic activity after the Samos earthquake. The earthquake magnitude distribution graph shows that most of the aftershocks range in magnitude from 3.5 to 4.5 . Besides, aftershocks started to decrease numerically within 7-10 days. Figure 5 also shows that most earthquakes occurred in depth ranging from 5 to $10 \mathrm{~km}$. Although it is located in a remote location, these earthquakes also affected Bayraklı and its environs.

Diver records in groundwater monitoring wells indicating possible groundwater-level changes due to this earthquake are shown below. Artificial anomaly corrections during the measurements were made in all data, and water levels were corrected for barometric pressure. Also, there was no rainfall recorded in İzmir and environs during this study period. For this reason, it is not possible to feed on rainfall or withdraw water from another well around the observation wells.

In Figure 6, a time-dependent graph of temperature measurements taken from 5 different wells (S1, S3, S6, S7, and S9) at 1-h intervals is given. During the period of 1-2 days before the Samos earthquake, changes in the temperature of the wells were detected. While these anomalies were in the form of temperature increase in wells S1 and S3, temperature decreases were observed in other wells. This situation is thought to be related to mixing groundwaters with seawater because these two wells are the closest ones to the sea. During the earthquake, the temperature values in all wells decreased significantly for a short time and then rose suddenly to a level close to or higher than the previous level. It is thought that the reason for this is the entry of new groundwater from the outside into the stagnant well with earthquake waves. Similarly, temperature changes in the wells on the 17 and 20 November earthquakes can be observed in the graph before the earthquake. 


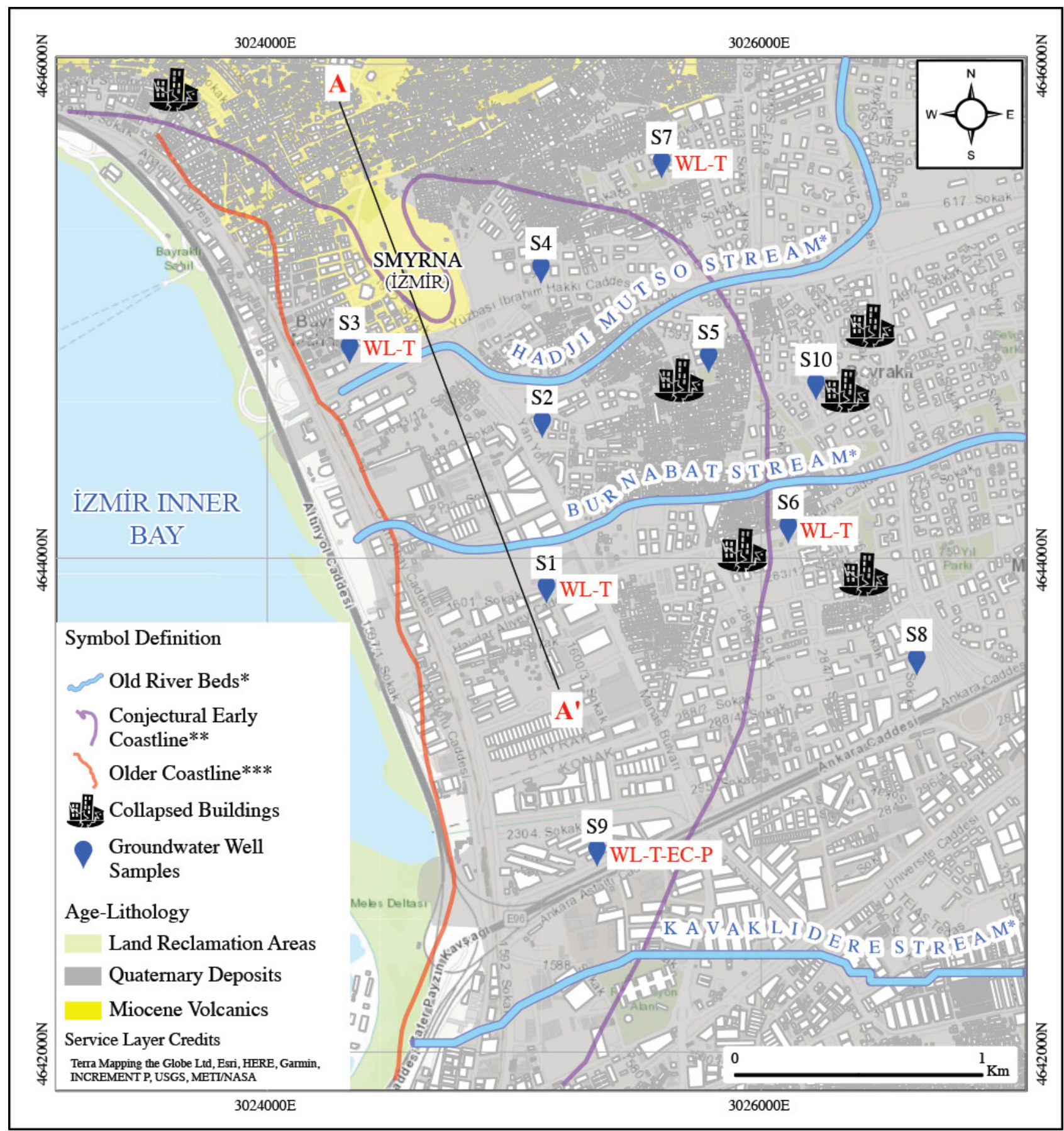

Figure 3. Geological map of the Bayraklı region with well locations (S-samples) and collapsed buildings $\left({ }^{*}\right.$ Old river beds, ${ }^{* *}$ conjectural early coastline and ${ }^{* * *}$ older coastline projected and added the map from Jones (1939); Diver types: WL-water level, T-temperature, ECelectrical conductivity, P-barometric pressure).

Groundwater level monitoring systems can be performed at different time intervals, such as long and short-term changes in earthquakes (Rosen et al., 2018; Senthilkumar et al., 2020). Systems that monitor groundwater changes have been installed in many regions around the world, and relevant studies and observations were made (Van Duijvenboodem et al., 1993; Hsu, 1998; Manga and Wang, 2007; 2015; Little et al., 2016; Gejl et al., 2019; Sun et al., 2019). In previous similar studies, water level changes (rise and fall) from $15 \mathrm{~cm}$ to $65 \mathrm{~cm}$ during and after an earthquake were reported (Chia et al., 2001; Roeloffs et al., 2011; Lee and Woo, 2012; Chen et 


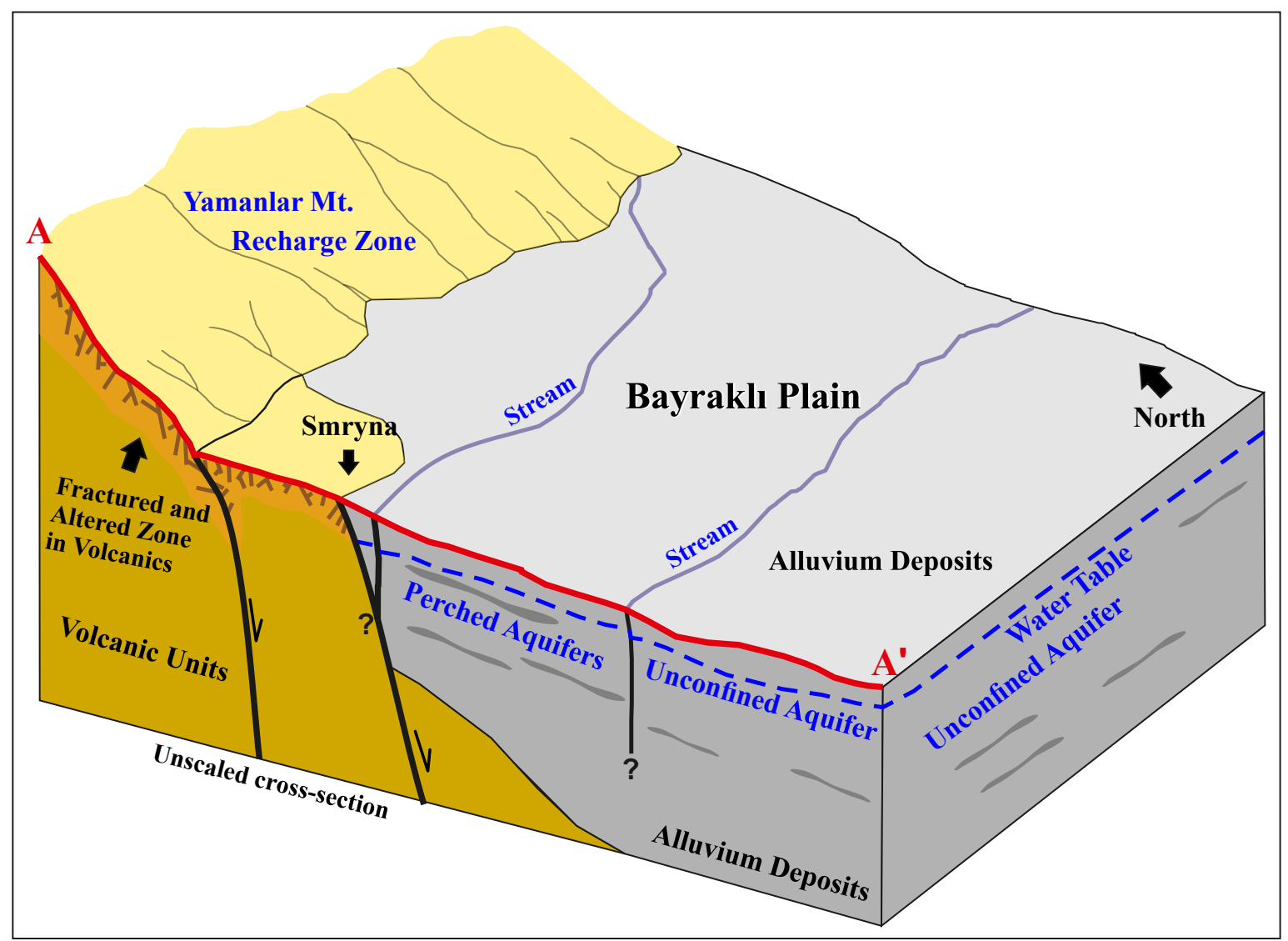

Figure 4. Hydrogeological model of the Bayraklı Plain (see Figure 3 for location of the cross-section line A-A').

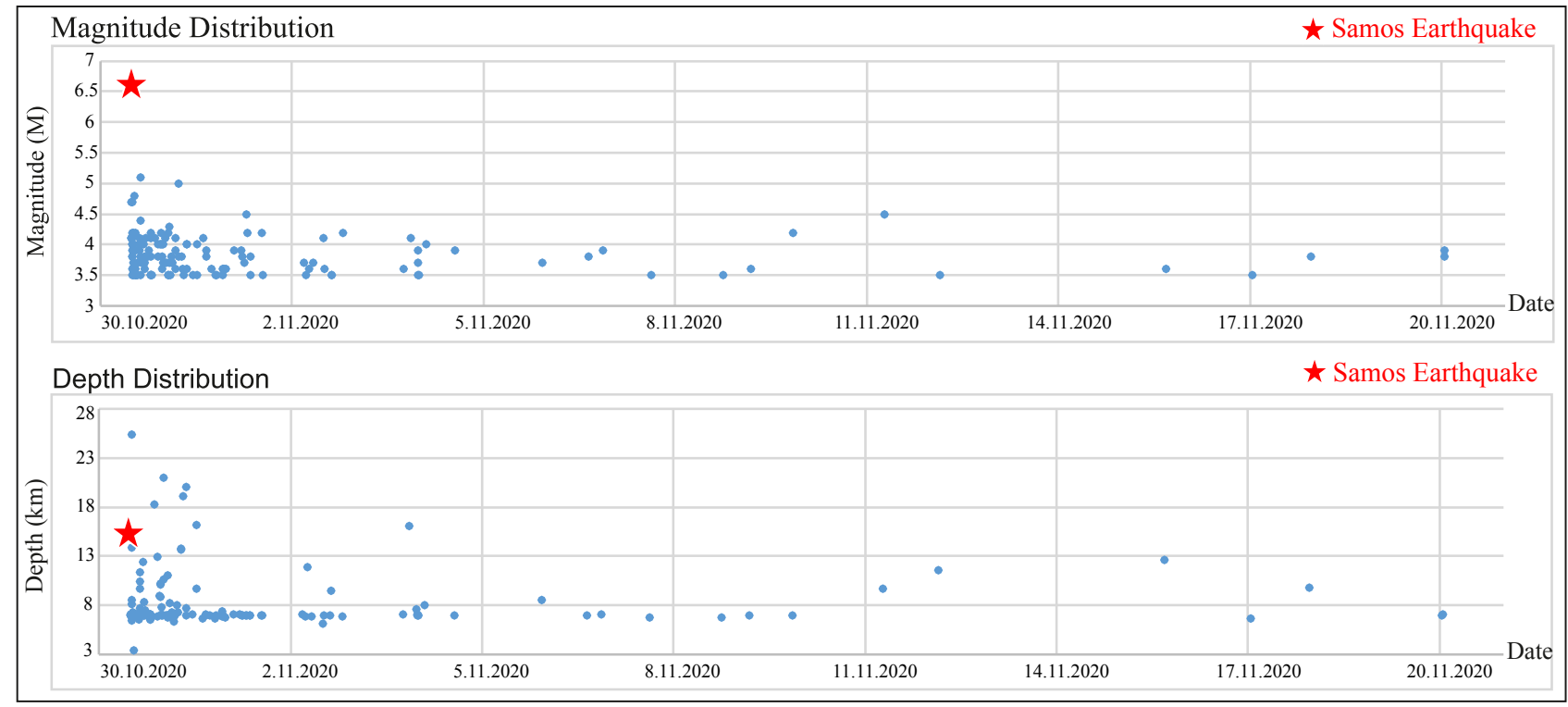

Figure 5. Magnitude-time and depth-time distribution of Samos earthquake swarm.

al., 2013; Koizumi, 2013; Lee et al., 2013; Yun et al., 2019; Senthilkumar et al., 2020). These sudden changes in well levels during an earthquake are related to the formation of a chaotic environment and even turbulence with shaking in the groundwater environment and aquifers. It is known that there are changes in pore pressure due to the strain 


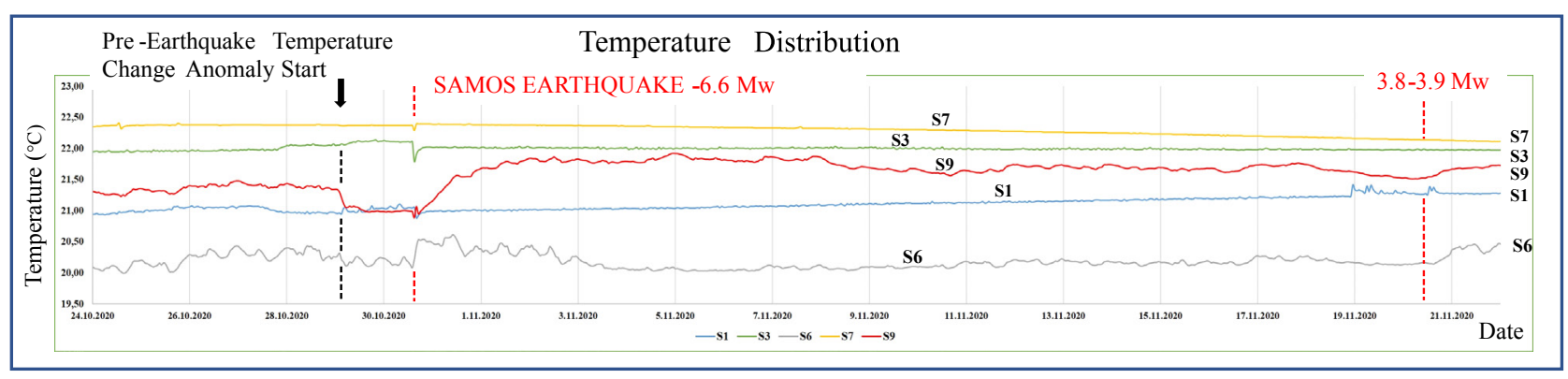

Figure 6. Water temperature-time distribution of five monitoring wells before and after the Samos earthquake.

effect that occurs during an earthquake, especially in units containing groundwater (Cooper et al., 1965; Koizumi, 2013; He and Singh, 2019).

Similarly, observation well monitoring was recorded changes in groundwater levels in shallow wells with a depth of $10 \mathrm{~m}$ in the area of Bayraklı. In Figure 7, timedependent graphs of groundwater levels of 5 different wells (S1, S3, S6, S7, and S9) are given. Divers recorded an interesting pre-seismic indicator of water level arising two days before the earthquake event. Groundwater level data clearly show that the water level rose sharply approximately $10 \mathrm{~cm}$, and levels maintained or increased until the earthquake. It took place about 7-10 days after the mainshock for the water levels to recover their former static levels.

Additionally, a significant correlation was found between the period of recovery of groundwater levels to pre-earthquake levels and the continuity of aftershocks. As can be seen from Figure 5, the dates of intense earthquakes with a magnitude greater than 3.5 and the time interval when water levels remained higher than pre-earthquake levels are almost the same, and both lasted 7-10 days. This is an indication that seismic activity can keep water levels under control for a certain period, in addition to causing sudden increases in groundwater levels.

During the Samos earthquake swarm (from October 30 to November 7, 2020), instantaneous level changes caused by aftershocks were observed in some wells. However, a chaotic environment occurs in groundwaters after an earthquake, the levels are already high, or it is necessary to take detailed measurements in narrower time intervals due to frequent earthquakes. Since diver measurements are taken every 1 - $\mathrm{h}$ in this process, it would be wrong to make a general comment for all wells for now.

However, towards the end of November, the aftershocks diminished, water level oscillations were detected again in two different earthquakes. Earthquakes with magnitudes of 3.8 at $23: 00$ on $17.11 .2020 ; 3.8$ at $00: 58$ on 20.11.2020, and 3.9 at $01: 13$ caused groundwater level changes again. While the groundwater levels rise before the earthquake can be seen clearly in wells S1, S6, and S9, it is possible to determine and to recognize the increase in wells S3 and S7 by focusing on the water level's differentiation trend.

In addition to groundwater level observations, studies were conducted to determine the physical and hydrogeochemical character of groundwater (Figure 8 and Table). For this purpose, water samples were collected from 10 wells; physical and chemical analyses were carried out at regular intervals.

According to the sample measurement results, the $\mathrm{pH}$ values of the waters vary between 6.91 and 7.37. EC values range from 888 to $2380 \mu \mathrm{S} / \mathrm{cm}$. The high EC values were measured in wells close to the sea, such as S9 and S1, while low EC values were measured in wells such as S7 and S8 at topographically higher elevations. $\mathrm{Na}^{+}$and $\mathrm{Cl}^{-}$ion concentrations are also high in $\mathrm{S} 9$ and $\mathrm{S} 1$ wells, similar to EC values. As can be seen in Piper and Schoeller diagrams (Figure 8), these wells have higher $\mathrm{Na}^{+}$and $\mathrm{Cl}^{-}$ concentrations than other waters, which indicates that these wells are affected by seawater intrusions.

$\mathrm{K}^{+}$and $\mathrm{Mg}^{2+}$ concentrations are also higher in shoreline wells. These two ions are closely associated with $\mathrm{Na}^{+}$. While $\mathrm{Mg}^{2+}$ is generally derived from limestone and dolomites together with $\mathrm{HCO}_{3}^{-}, \mathrm{K}^{+}$is mixed with groundwaters from clay minerals (possibly related with perched aquifers) such as illite.

It is to expect an increase in major ions in waters due to water-rock interactions after an earthquake. However, since there is no reliable water hydrogeochemistry data before the earthquake, it will not be very accurate to associate hydrogeochemistry data with seismic activity. However, when the pre-earthquake EC values were monitored both in the field and with instantaneous in-well divers, increases in EC values were determined during and after the earthquake. The observation of these increases with water-rock interactions and especially in wells close to the seashore and stream beds, indicates that seawater intrusion occurred.

The only well in which EC values are measured with the diver is the S9 well (Figure 7). EC value range shows that rock-water interactions increased with the tension before the earthquake, and then waters with high EC 
S1

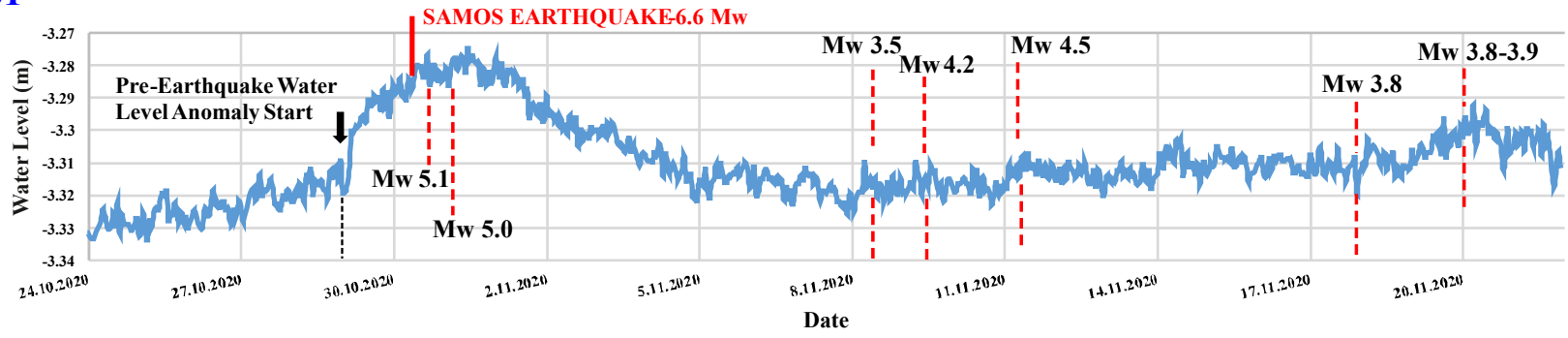

S3

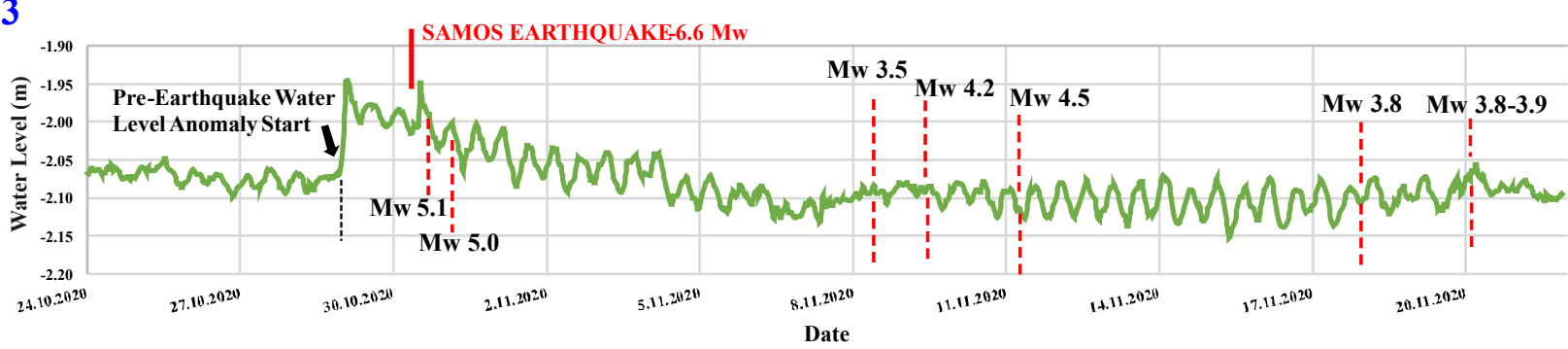

S6

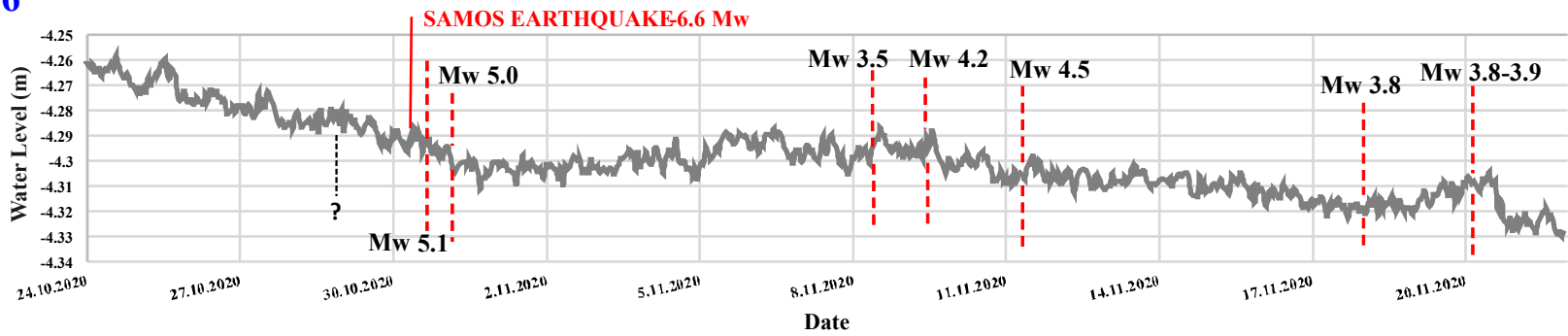

S7
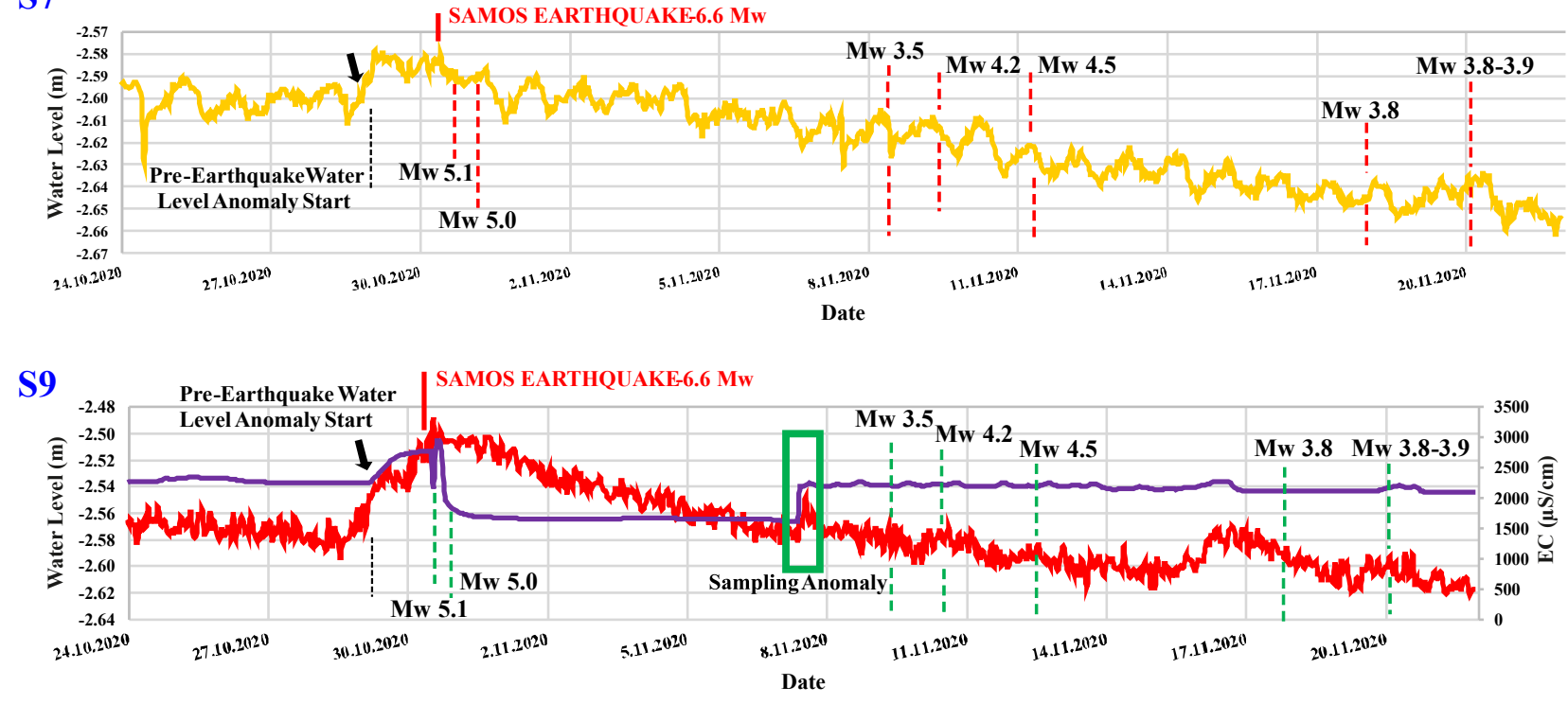

-Water Level Electrical Conductivity (EC)

Figure 7. Water-level and EC changes before and after the Samos earthquake. 


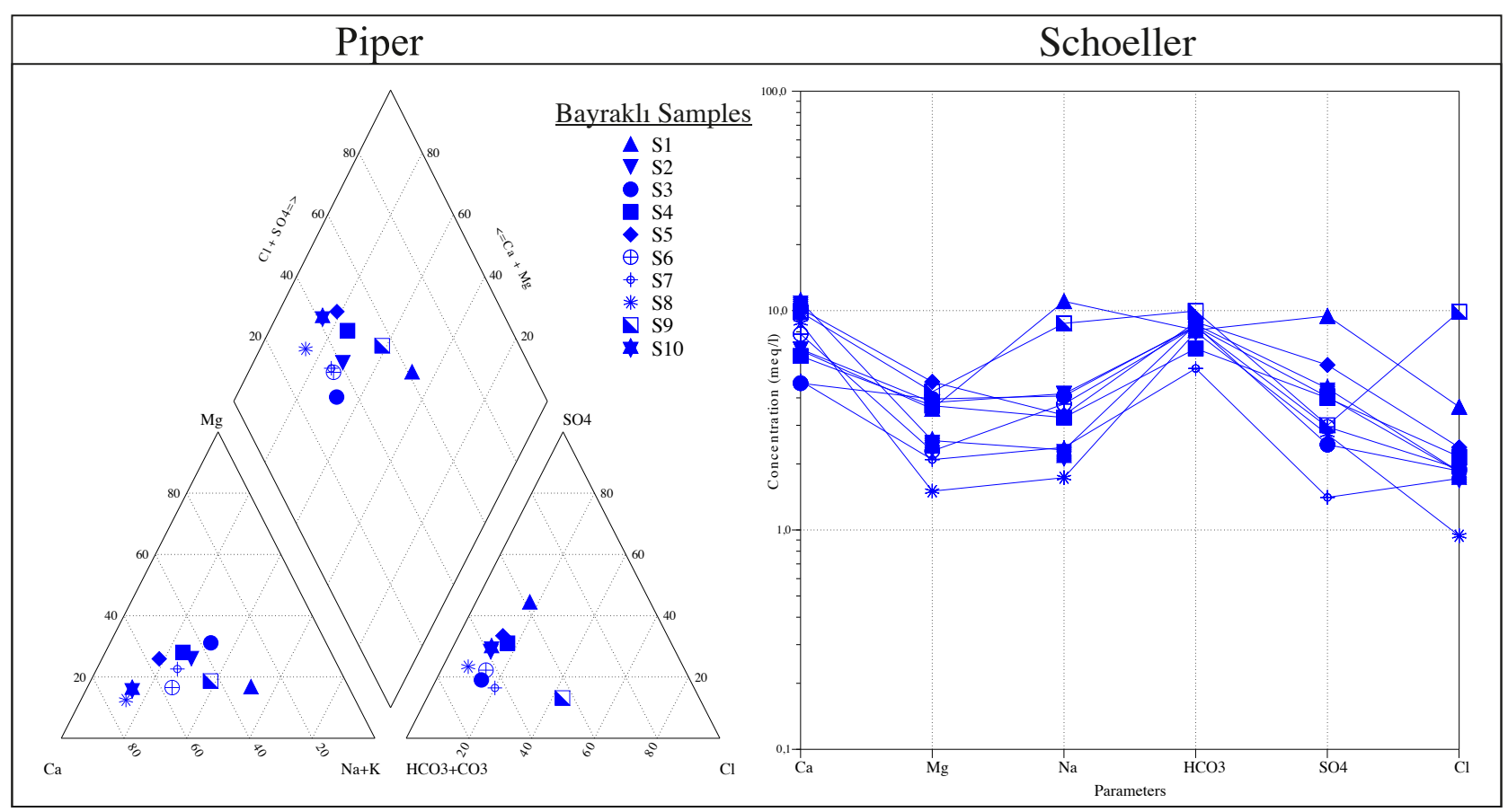

Figure 8. a) Piper diagram and b) Schoeller diagram of groundwater samples from the Bayraklı region.

mixed into the well and increased the water level. After the earthquake, the water left the well with the shaking, and the well started to return slowly to its former state. However, with the water sampling conducted within the scope of this study, this process accelerated and caused a disturbance with vertical hydraulic diffusivity of the material at the bottom (Figure 7, in graph S9 labeled as "sampling anomaly"). The materials suspended in the water body in the well collapse to the bottom due to gravitational forces during the earthquake, but EC values returned to the pre-earthquake values in the well with sampling. After a short time, the rising EC values remained stable at preearthquake conditions and continued to show momentary anomalies again as a result of aftershocks on October 20.

The increase in the water level and electrical conductivity observed in the wells with the earthquake shaking occurred due to the increase in permeability and porosity properties of alluvium units for a certain period. This situation brings about a riskier situation for Holocene deltas and other Quaternary deposits, riverbeds-terraces, floodplains, and reclamation areas near the sea. During the earthquake, the pore water pressure in saturated sandy soil will increase due to the tendency of the volume contraction if the drainage of the water is impeded. This results in lower effective stress and the reduction of strength, and even the liquefaction of the sand. Liquefaction takes place when a saturated soil substantially loses strength in response to applied stress or seismic activity. Liquefaction occurring beneath buildings and other structures can cause significant damage, such as the collapse of buildings, bridges, and towers during earthquakes.

California earthquake (1989), Japan-Niigata earthquake (1964), Japan-Tokyo Bay earthquake (2011), and Kocaeli earthquake (1999) are some of the most important examples of earthquake induced liquefaction. Especially Karşıyaka, Mavişehir and Bayraklı districts of İzmir, where there are ground conditions similar to those in the regions where the mentioned earthquakes occurred, are also very risky regions in terms of liquefaction. Within the scope of this study, wells were drilled in Bayraklı in the first $10 \mathrm{~m}$, and groundwater level varies between 2 and $5 \mathrm{~m}$ in the dry period. It is observed that floods and sea elevations on the northern shores of İzmir Bay during rainy periods increase with each passing year. For this reason, the high groundwater level in Bayrakl is a situation that should be considered in terms of liquefaction and soil problems.

\subsection{Physical and chemical changes in geothermal fields} Apart from temperature and pressure conditions, aquifer and cap rock properties with structural controls are primary control mechanisms for both geothermal waters and groundwaters. With the samples taken from geothermal waters, it is possible to determine the physical and chemical changes as in groundwater. Therefore, observations must have been made before and after the earthquakes to determine the response in two of the geothermal fields in İzmir. 


\begin{tabular}{|c|c|c|c|c|c|c|c|c|c|c|c|c|c|c|c|c|c|c|c|c|}
\hline 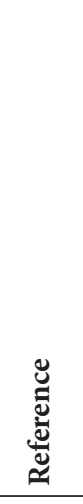 & 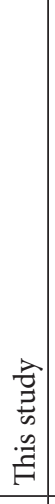 & 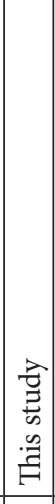 & 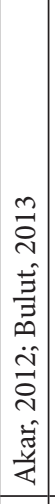 & 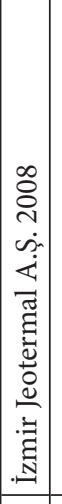 & 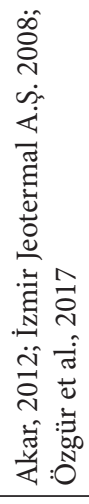 & 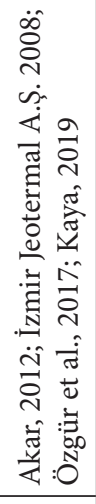 & 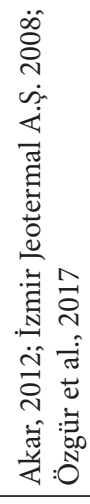 & 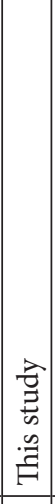 & 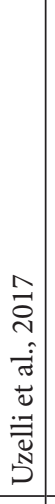 & 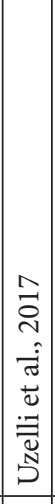 & 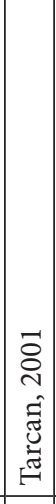 & 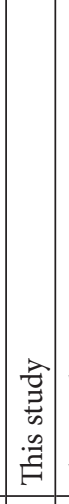 & 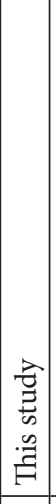 & 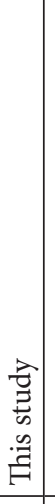 & 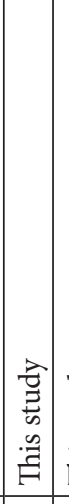 & 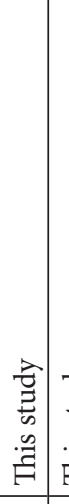 & 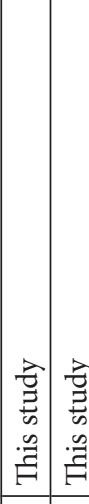 & 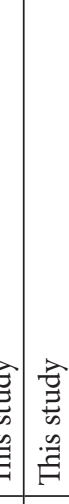 & 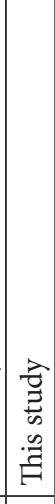 & 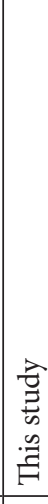 \\
\hline$\dot{S}^{m}$ & \begin{tabular}{l}
$\forall$ \\
\multirow{H}{*}{} \\
$\dot{8}$ \\
$i n$ \\
\end{tabular} & \begin{tabular}{|l|}
$z$ \\
$\vdots$ \\
0 \\
0 \\
$i$ \\
\end{tabular} & 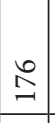 & 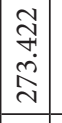 & $\begin{array}{l}n ? \\
0 \\
\infty \\
m \\
m\end{array}$ & 옴 & $\vec{n}$ & $\begin{array}{l}\stackrel{\text { m}}{ } \\
+ \\
\stackrel{n}{n}\end{array}$ & $\begin{array}{l}+1 \\
0 \\
0 \\
0 \\
-\end{array}$ & \begin{tabular}{|l|} 
\\
0 \\
0 \\
0 \\
0 \\
\end{tabular} & 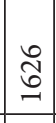 & \begin{tabular}{|c|} 
\\
0 \\
$\dot{0}$ \\
$\dot{\gamma}$ \\
\end{tabular} & \begin{tabular}{|c|}
\multirow{n}{*}{} \\
$i n$ \\
\end{tabular} & 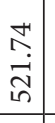 & \begin{tabular}{|c|} 
\\
0 \\
$\infty$ \\
$\dot{a}$ \\
$\dot{+}$ \\
\end{tabular} & $\begin{array}{l}2 \\
\alpha \\
0 \\
\vdots \\
n \\
n\end{array}$ & 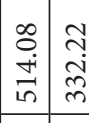 & $\begin{array}{lll}v & \vec{m} \\
\text { ve } & \infty \\
& \infty \\
\hat{n} & \infty \\
\end{array}$ & \begin{tabular}{|l|}
0 \\
0 \\
0 \\
0 \\
0 \\
\end{tabular} & \begin{tabular}{l}
\multirow{N}{N}{} \\
กิ \\
\end{tabular} \\
\hline $0^{N}$ & 2 & $\stackrel{2}{\circ}$ & 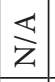 & $\stackrel{\stackrel{2}{\beth}}{\simeq}$ & $\hat{m}$ & $\Re$ & $\begin{array}{l}n ? \\
\text { in }\end{array}$ & 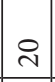 & $\overleftrightarrow{\mathrm{z}}$ & 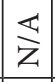 & $\infty$ & $\stackrel{\sim}{d}$ & $\infty$ & กิ & 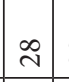 & \begin{tabular}{l|l}
$\infty$ & $\vdots$ \\
\end{tabular} & \begin{tabular}{l|l}
$\tilde{m}$ & $\forall$ \\
\end{tabular} & + & $\infty$ & in \\
\hline$\dot{D}^{+}$ & 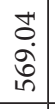 & \begin{tabular}{|c|}
$\infty$ \\
0 \\
$i$ \\
$\infty$ \\
$i$ \\
$i$ \\
\end{tabular} & $\stackrel{m}{\rightleftarrows}$ & $\stackrel{0}{7}$ & ఏ & ¿े & ָn & 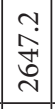 & $\begin{array}{l}0 \\
\stackrel{0}{0} \\
\grave{े} \\
\text { iे }\end{array}$ & \begin{tabular}{|l|}
$n$ \\
\\
\\
\\
\\
\end{tabular} & $\begin{array}{l}\vec{\pi} \\
\tilde{n}\end{array}$ & 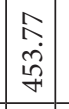 & 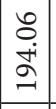 & $\begin{array}{l}\sqrt[n]{n} \\
\\
\end{array}$ & \begin{tabular}{|l|} 
\\
$\infty$ \\
$\dot{a}$ \\
\\
\end{tabular} & \begin{tabular}{c|l}
$\stackrel{1}{i}$ & \\
& \\
& $\vdots$ \\
\end{tabular} & 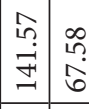 & 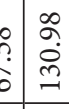 & $\begin{array}{l}n \\
0 \\
\dot{J} \\
\end{array}$ & $\begin{array}{l}\vec{J} \\
\stackrel{J}{N}\end{array}$ \\
\hline$\dot{U}$ & \begin{tabular}{|c|}
$\infty$ \\
$\infty$ \\
$\infty$ \\
\\
\\
\end{tabular} & 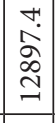 & $\begin{array}{l}\stackrel{N}{N} \\
\stackrel{1}{N} \\
\end{array}$ & \begin{tabular}{|l|}
$\stackrel{2}{2}$ \\
$\stackrel{\text { I }}{二}$ \\
\end{tabular} & $\begin{array}{l}\mathscr{1 0} \\
\text { oे } \\
\stackrel{0}{=}\end{array}$ & 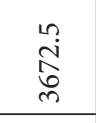 & $\stackrel{\stackrel{\sim}{\sim}}{\sim}$ & 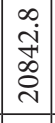 & $\begin{array}{l}\infty \\
\underset{\sim}{\sim} \\
\underset{\sim}{\sim} \\
\end{array}$ & 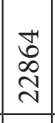 & $\begin{array}{l}\mathcal{Z} \\
\mathbb{Z} \\
\mathbb{N} \\
\end{array}$ & 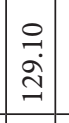 & $\begin{array}{c}7 \\
7 \\
8 \\
8\end{array}$ & $\begin{array}{l}0 \\
0 \\
1 \\
b\end{array}$ & 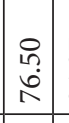 & $\underset{\infty}{\infty}$ & \begin{tabular}{|c|c} 
& 8 \\
$i$ \\
$\hat{b}$ & 8 \\
\end{tabular} & 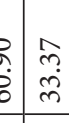 & $\begin{array}{l}m \\
\cdots \\
0 \\
0 \\
m \\
m\end{array}$ & 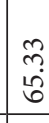 \\
\hline త్ & $\begin{array}{l}1 \\
0 \\
0 \\
0 \\
0 \\
\infty \\
\infty\end{array}$ & 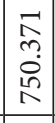 & $\overrightarrow{5}$ & $\frac{\infty}{6}$ & $\sqrt{6}$ & $\underset{\sim}{\stackrel{D}{N}}$ & $\stackrel{\infty}{\circ}$ & $\begin{array}{l}a \\
\infty \\
\stackrel{0}{0} \\
\Xi\end{array}$ & $\begin{array}{l}\infty \\
\stackrel{0}{0} \\
0 \\
- \\
\end{array}$ & 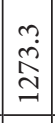 & \begin{tabular}{|c|}
0 \\
$i$ \\
$i$ \\
$i n$ \\
\end{tabular} & \begin{tabular}{|c|}
$\vec{b}$ \\
$\dot{0}$ \\
$\tilde{n}$ \\
\end{tabular} & \begin{tabular}{|l|}
$\hat{N}$ \\
$\stackrel{m}{-}$ \\
\end{tabular} & $\begin{array}{l}\infty \\
+ \\
\\
\sigma\end{array}$ & \begin{tabular}{l|}
$\vec{F}$ \\
$\stackrel{+}{+}$ \\
$\underset{J}{J}$
\end{tabular} & \begin{tabular}{l|l}
$\stackrel{n}{m}$ & \\
$\stackrel{0}{0}$ & \\
$\stackrel{n}{2}$ &
\end{tabular} & 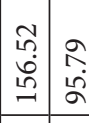 & 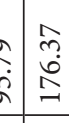 & $\begin{array}{l}\infty \\
\stackrel{2}{1} \\
\stackrel{2}{2} \\
\end{array}$ & 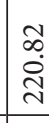 \\
\hline 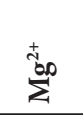 & 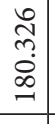 & 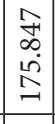 & $\begin{array}{l}\infty \\
\curvearrowright \\
\end{array}$ & $\widehat{\Xi}$ & in & N & in & $\begin{array}{l}0 \\
\dot{a} \\
a \\
\end{array}$ & $\stackrel{ }{\Xi}$ & $\begin{array}{l}0 \\
\stackrel{0}{=} \\
=\end{array}$ & 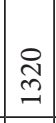 & $\mid \begin{array}{c}\tilde{m} \\
\tilde{P} \\
\tilde{F}\end{array}$ & 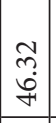 & 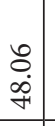 & $\begin{array}{l}\Omega \\
\stackrel{+}{+} \\
\end{array}$ & 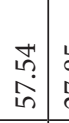 & 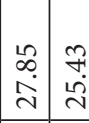 & 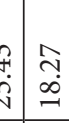 & $\begin{array}{l}+ \\
\infty \\
\dot{1} \\
\end{array}$ & 芫 \\
\hline \pm & 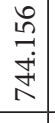 & 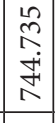 & 客 & $\vec{n}$ & $\stackrel{8}{\infty}$ & 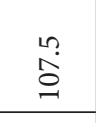 & $\begin{array}{l}\stackrel{10}{10} \\
\stackrel{10}{Z}\end{array}$ & $\begin{array}{c}0 \\
0 \\
\infty \\
o \\
o+1 \\
\end{array}$ & $\stackrel{+}{\circ}$ & \begin{tabular}{|l|} 
\\
ț \\
\end{tabular} & 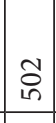 & \begin{tabular}{l|}
$\tilde{T}$ \\
$\ddot{\sim}$ \\
$\tilde{\sim}$
\end{tabular} & \begin{tabular}{|l}
$\hat{a}$ \\
$\hat{m}$ \\
m.
\end{tabular} & $\begin{array}{l}2 \\
\ddot{2} \\
\\
\end{array}$ & $\begin{array}{c}\tau \\
\tilde{d} \\
\dot{\sim} \\
\end{array}$ & $\begin{array}{l}\overrightarrow{7}: 2 \\
\therefore\end{array}$ & 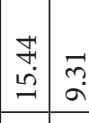 & $\begin{array}{lll}\vec{n} \\
\end{array}$ & $\begin{array}{l}\partial \\
\partial \\
\end{array}$ & $\begin{array}{l}8 \\
\text { in } \\
\text { a }\end{array}$ \\
\hline 艺 & $\begin{array}{l}\mathcal{N} \\
\underset{\mathcal{Z}}{\mathrm{d}} \\
\mathrm{O}\end{array}$ & \begin{tabular}{l|}
$\infty$ \\
$\hat{\beta}$ \\
$\hat{\sigma}$ \\
$\hat{\sigma}$ \\
\end{tabular} & 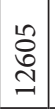 & 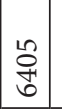 & స్రิ & 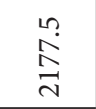 & $\underset{J}{\stackrel{Z}{J}}$ & $\begin{array}{l}\hat{\sigma} \\
\exists \\
\exists\end{array}$ & 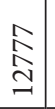 & 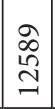 & $\begin{array}{l}\vec{b} \\
\stackrel{\Xi}{\Xi} \\
\end{array}$ & $\mid$\begin{tabular}{c|}
$\tilde{\alpha}$ \\
$\hat{\sigma}$ \\
$\tilde{\sim}$
\end{tabular} & 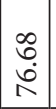 & $\begin{array}{l}\stackrel{+}{N} \\
\stackrel{\infty}{\infty} \\
\stackrel{\infty}{*}\end{array}$ & $\begin{array}{l}\hat{f} \\
\mathrm{i} \\
\mathrm{\sigma}\end{array}$ & \begin{tabular}{l|l}
$\infty$ & $\infty$ \\
& \\
& 1 \\
\end{tabular} & 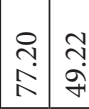 & 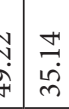 & $\begin{array}{l}\vec{m} \\
\stackrel{\alpha}{\sigma} \\
\vec{\sigma}\end{array}$ & 종 \\
\hline$\stackrel{\Xi}{\tilde{D}}$ & 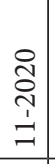 & 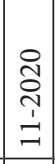 & 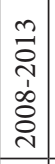 & 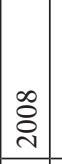 & 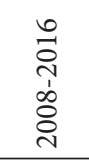 & 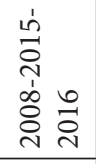 & 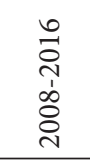 & 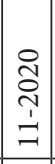 & $\underset{⿱}{\stackrel{+}{i}}$ & $\begin{array}{l}+ \\
\stackrel{2}{\vec{c}} \\
\end{array}$ & $\overrightarrow{8}$ & 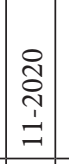 & 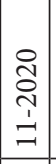 & $\begin{array}{l}\stackrel{0}{0} \\
\stackrel{0}{1} \\
\Xi \\
=\end{array}$ & 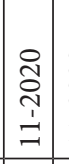 & \begin{tabular}{l|l}
$\stackrel{0}{0}$ & \\
& $\vdots$ \\
$=$ &
\end{tabular} & 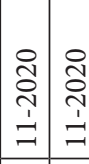 & 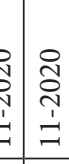 & 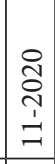 & 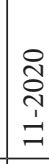 \\
\hline$H \stackrel{\star \star}{0}$ & $\stackrel{m}{m}$ & $\infty$ & ‡ి & $\stackrel{20}{=}$ & ๙ิ) & $\begin{array}{l}0 \\
\stackrel{0}{1}\end{array}$ & ڤิ่ & $\begin{array}{l}\infty \\
\tilde{n} \\
\tilde{n} \\
\end{array}$ & $\stackrel{m}{m}$ & $\begin{array}{l}10 \\
\tilde{m} \\
\end{array}$ & $\overleftrightarrow{\mathrm{z}}$ & $\begin{array}{l}\stackrel{i}{\vdots} \\
\vec{i}\end{array}$ & $\begin{array}{c}0 \\
\dot{q} \\
\ddot{n} \\
\end{array}$ & 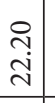 & $\mid \begin{array}{l}0 \\
0 \\
i \\
i\end{array}$ & \begin{tabular}{l|l}
$\infty$ & \\
$\vec{i}$ &
\end{tabular} & \begin{tabular}{|c|c}
8 & 0 \\
$\vec{i}$ & $\stackrel{n}{i}$ \\
\end{tabular} & 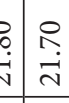 & $\begin{array}{l}\stackrel{2}{2} \\
\text { iे }\end{array}$ & $\begin{array}{l}\text { : } \\
\stackrel{i}{0}\end{array}$ \\
\hline ن & 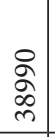 & 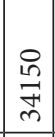 & 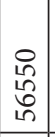 & \begin{tabular}{|l} 
¿े \\
$\grave{2}$ \\
m.
\end{tabular} & 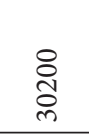 & $\stackrel{̊}{\leftrightarrows}$ & $\stackrel{\stackrel{2}{4}}{ה}$ & $\begin{array}{l}8 \\
8 \\
8 \\
0 \\
i n \\
\hat{n} \\
\end{array}$ & $\begin{array}{l}8 \\
\stackrel{0}{0} \\
\stackrel{N}{n} \\
\hat{n}\end{array}$ & $\begin{array}{l}8 \\
8 \\
\dot{8} \\
\mathbb{N} \\
\hat{n} \\
\end{array}$ & \begin{tabular}{|l|}
0 \\
0 \\
$\dot{0}$ \\
0 \\
$\infty$ \\
$i n$ \\
\end{tabular} & \begin{tabular}{|c|}
0 \\
\\
\\
0 \\
- \\
-1
\end{tabular} & \begin{tabular}{|c|}
0 \\
$\dot{2}$ \\
$\grave{i}$ \\
\end{tabular} & $\begin{array}{l}0 \\
i \\
\infty \\
= \\
=\end{array}$ & 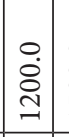 & \begin{tabular}{l|l}
0 & \\
$\infty$ & \\
$\infty$ & 1 \\
0 & 1 \\
- &
\end{tabular} & 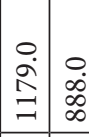 & 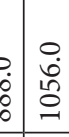 & $\begin{array}{l}0 \\
\dot{0} \\
0 \\
\tilde{i} \\
\end{array}$ & $\begin{array}{l}0 \\
\stackrel{+}{0} \\
\stackrel{\sim}{\sim}\end{array}$ \\
\hline 索 & $\begin{array}{l}0 \\
\dot{6}\end{array}$ & $\hat{\sigma}$ & $\begin{array}{ll}1 \\
\infty \\
\infty\end{array}$ & $\stackrel{i n}{n}$ & $\stackrel{0}{6}$ & $\stackrel{n}{1}$ & $\vec{n}$ & ఠ̧ & $\stackrel{\circ}{\Gamma}$ & $\stackrel{0}{1}$ & $\begin{array}{l}\infty \\
\infty \\
\infty\end{array}$ & \begin{tabular}{|l|}
$\stackrel{\infty}{0}$ \\
$\stackrel{2}{\wedge}$ \\
\end{tabular} & \begin{tabular}{l}
0 \\
\hdashline \\
\end{tabular} & 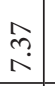 & $\stackrel{?}{\curvearrowright}$ & $\vec{\therefore}$ & $\begin{array}{ll}\stackrel{0}{n} & \hat{\sigma} \\
\end{array}$ & 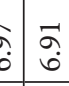 & ఫે & $\begin{array}{l}8 \\
\end{array}$ \\
\hline 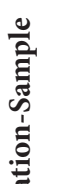 & 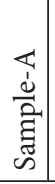 & 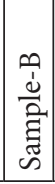 & 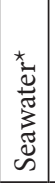 & 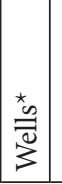 & 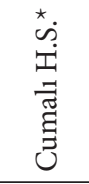 & 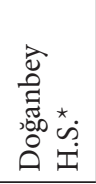 & 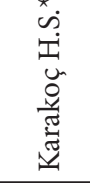 & 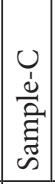 & 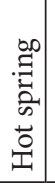 & 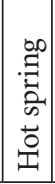 & 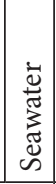 & $\vec{n}$ & $\tilde{\omega}$ & $n$ & 芯 & $\begin{array}{lll}0 & 0 \\
0 & 0 & 0\end{array}$ & 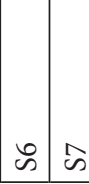 & $\begin{array}{l}\infty \\
\infty\end{array}$ & के & 号 \\
\hline 过 & \multicolumn{7}{|c|}{ 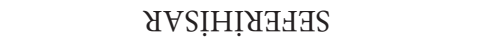 } & \multicolumn{4}{|c|}{ 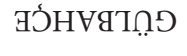 } & \multicolumn{9}{|c|}{ ITY $\forall Y X \forall G$} \\
\hline
\end{tabular}


Seferihisar and Gülbahçe geothermal fields are located approximately 20 and $50 \mathrm{~km}$ north of the earthquake epicenter, respectively. As a result of these observations made in the geothermal fields after the earthquake, it was determined that some physical and hydrogeochemical responses were formed against the earthquake. Most of these responses gradually decreased their effects within the month after the earthquake. This situation shows that the earthquake on the North Samos Fault affected the geothermal waters and faults with different characteristics in the north of the region. The tsunami in the region also reveals a different dimension of the earthquake (Sözbilir et al., 2020).

\subsubsection{The Gülbahçe geothermal field}

Gülbahçe Fault Zone (GFZ) has a connection with seawater along with the fault segments in the Gülbahçe Bay (Figure 9). Therefore, meteoric waters, geothermal waters, and seawater could easily mix in this area. After the Samos earthquake, fault segments reacted to the shaking of the earthquake and show responses with different reactions.

The first anomaly was observed in the flow rate and temperature changes of geothermal waters. The Gülbahçe geothermal field is located on the eastern segment of the GFZ. There is also an ancient Roman bath that was built on a location of geothermal spring in fractured limestones. The highest discharge location with a flow rate of 15-20 1/s emerges in a bath at the intersection of N-S and NE-SW trending fault sets. After the earthquake, the temperature of the bath increased from $33{ }^{\circ} \mathrm{C}$ to $35^{\circ} \mathrm{C}$, and this minor change stabilized 4-5 days after the mainshock.

Second and the most important anomaly observed on the Gülbahçe shoreline. After the mainshock, new geothermal springs in the same water character as other geothermal springs in the vicinity were formed (Figure 10). It is a known phenomenon that there may be changes in the permeability and conductivity properties of rocks before and after earthquakes, especially in fault zones, which may affect the geothermal system and groundwaters in the region. These changes may cause a decrease/increase in the flow rate of the existing geothermal springs, wells and groundwaters. Also, situations such as new spring formation and losing activity of existing springs may be encountered (Rojstaczer and Wolf, 1992; Amoruso et al., 2011; Chen et al., 2013; Galassi et al., 2014; He and Singh, 2019; Senthilkumar et al., 2020).

Measured temperatures of geothermal waters which emerged after the earthquake, range from 35 to $38{ }^{\circ} \mathrm{C}$, and the flow rate decreases day by day (Figure 10). This observation shows that new channels opened with the earthquake, and geothermal waters ascend to the surface. After the swarm of earthquakes channels began to close again with the previous stress conditions in the area.
Another anomaly occurred in another location one day before the November 20 earthquakes in the north of Samos Island with magnitudes 3.8 and 3.9. A dense gas leakage was detected on a fault segment whose trace on land was mapped by geophysical methods and morphological findings (Uzelli et al., 2017), which is thought to be continuous in the sea (Figure 10d). Similar to the water level anomalies in the Bayraklı region, gas leakage occurred in the sea one day before the earthquake and disappeared the day after the earthquake. These observed gas leakages in the sea floor are proof that the steam in the geothermal system also reaches the surface along the activated fault planes.

The signs of liquefaction events were also observed in Gülbahçe geothermal field during this earthquake (Figure 11). In the west of the Roman bath, liquefaction and sand volcano formation took place in the gardens and agricultural lands. During the earthquake, the muddy material with a diameter of 4-5 meters reached the surface and activity ended one day after the earthquake. In addition to the sandy soil characteristics, the rising sea and groundwater levels due to precipitation and tides indicate that the area is risky in terms of liquefaction.

In the Gülbahçe geothermal system, faults and fractures within the basement limestones control the geothermal water flow and the hydrogeochemistry in karstic aquifers. The origin of $\mathrm{Na}-\mathrm{Cl}$ type geothermal waters reflects in hydrogeochemical analyses in Table (Figure 12). According to the previous and current hydrogeochemical analyses, the highest value of electrical conductivities of waters was measured in this study. The $\mathrm{pH}$ value of the sample (Sample-C) taken from the newly released waters is compatible with the water analyses of previous studies.

The fact that the relatively low ion concentrations $\left(\mathrm{Mg}^{2+}\right.$ and $\mathrm{Ca}^{2+}$ ) compared to the water analyses of previous studies indicates the origin of the seawaters less affected by the water-rock interaction since the geothermal waters reach the surface rapidly during an earthquake. More than chemical differences, the formation of new geothermal springs with the same water characteristics in the Gülbahçe geothermal field, the observation of gas leakage in the sea, and liquefaction are important findings showing that the regional faults were affected by the earthquake.

\subsubsection{The Seferihisar geothermal field}

The geothermal field of Seferihisar (also called as Tuzla) is a widespread geothermal system consisting of different subgeothermal fields such as Cumalı, Karakoç, and Doğanbey. This area has indirect and direct use applications. Further east, Orhanl, Akyar, and Ilıkpınar geothermal fields are also areas open to development actively today.

In the field of Seferihisar, the geothermal waters come from the basement units through fault segments. It is possible to see geothermal springs on the right- 


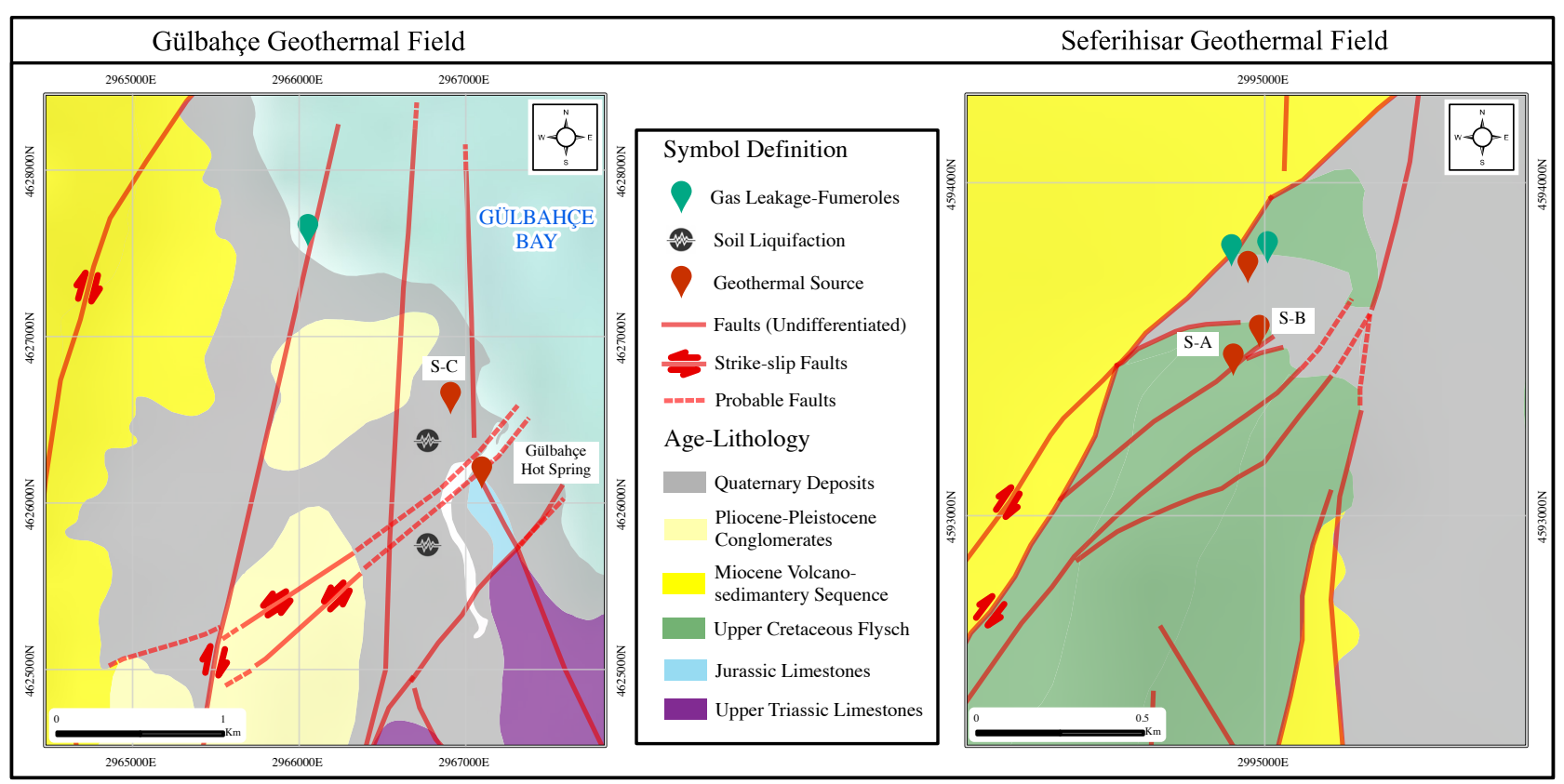

Figure 9. Geological maps of the Gülbahçe and Seferihisar geothermal fields (modified after Uzelli et al., 2017 and Eşder and Şimşek, 1975; S: Sample).

sided strike-slip segments of the Tuzla Fault and in the transtensional zones where the faults step-over and/or bend. It is known that faults allow the upwelling of deep mineralized geothermal waters and cause mixing with meteoric waters (Petitta et al., 2011; Barberio et al., 2017). Extension in lithostratigraphic units with earthquakes increases permeability and aperture size of the fault planes/cracks that allow the water circulation. It is also known that there are geothermal springs and small ponds close to this area. However, water channels on this fault plane gained activity after the earthquake. After the Samos earthquake, geothermal water outflow started on a fault segment on which paleoseismological trenching studies were carried out.

Physical and chemical analyses were made on the hightemperature geothermal waters coming from the depths after the earthquake on the Tuzla Fault. Temperatures of geothermal waters that reach the surface from the fault plane range from 78 to $99^{\circ} \mathrm{C}$ (Sample B). Figure 13 shows the view of the sources before and after the formation and the close-up view of the sources on the fault plane. In addition to geothermal water and steam, clayey-muddy hot water outflows were also observed (Figure 13c). EC values of the waters are very close to the $\mathrm{EC}$ values of deep geothermal production wells in the Cumalı region (Table). Higher EC and temperature values show that the geothermal system has a deep circulating geothermal water. The new geothermal waters are dominated by $\mathrm{Na}^{+}$ and $\mathrm{Cl}^{-}$since they reach the surface quickly along the faults from the same reservoir with other geothermal waters in the field. The water type of the newly emerged geothermal waters is reflected in the Piper and Schoeller diagrams (Figure 14), which has the highest concentration of all hydrogeochemical analyses sampled in this field (Table).

$\mathrm{Na}-\mathrm{Cl}$ type of waters can be gained by a result of interaction with sedimentary rocks containing evaporites, seawater, and deep-magmatic fluids. $\mathrm{Mg}^{2+}, \mathrm{Cl}^{-}$and $\mathrm{SO}_{4}^{2-}$ concentrations are higher than the analyses of previous studies, and this situation can be associated with the seismic activity, as stated in some other studies (Igarashi et al., 1995). The geothermal water and steam present in low-permeable units may have been forced into motion suddenly after an earthquake. In this case, high pressure, high temperature, and rapid water-rock interaction occurred and water samples may contain higher than normal concentrations of dissolved ions. Indeed, in the two samples of geothermal waters taken, the values are higher than the concentrations in previous studies, unlike the Gülbahçe geothermal field. This situation is thought to be related to the water's temperature and proximity to the heat source in the geothermal system.

After the earthquake, the regional stress regime in the area returned to pre-earthquake conditions, cracks and fault planes started to close, and the flow rate and temperature began to decrease with the precipitation of the minerals. However, long-term monitoring of geothermal system in the area will continue to be monitored to determine the continuity of this process. 


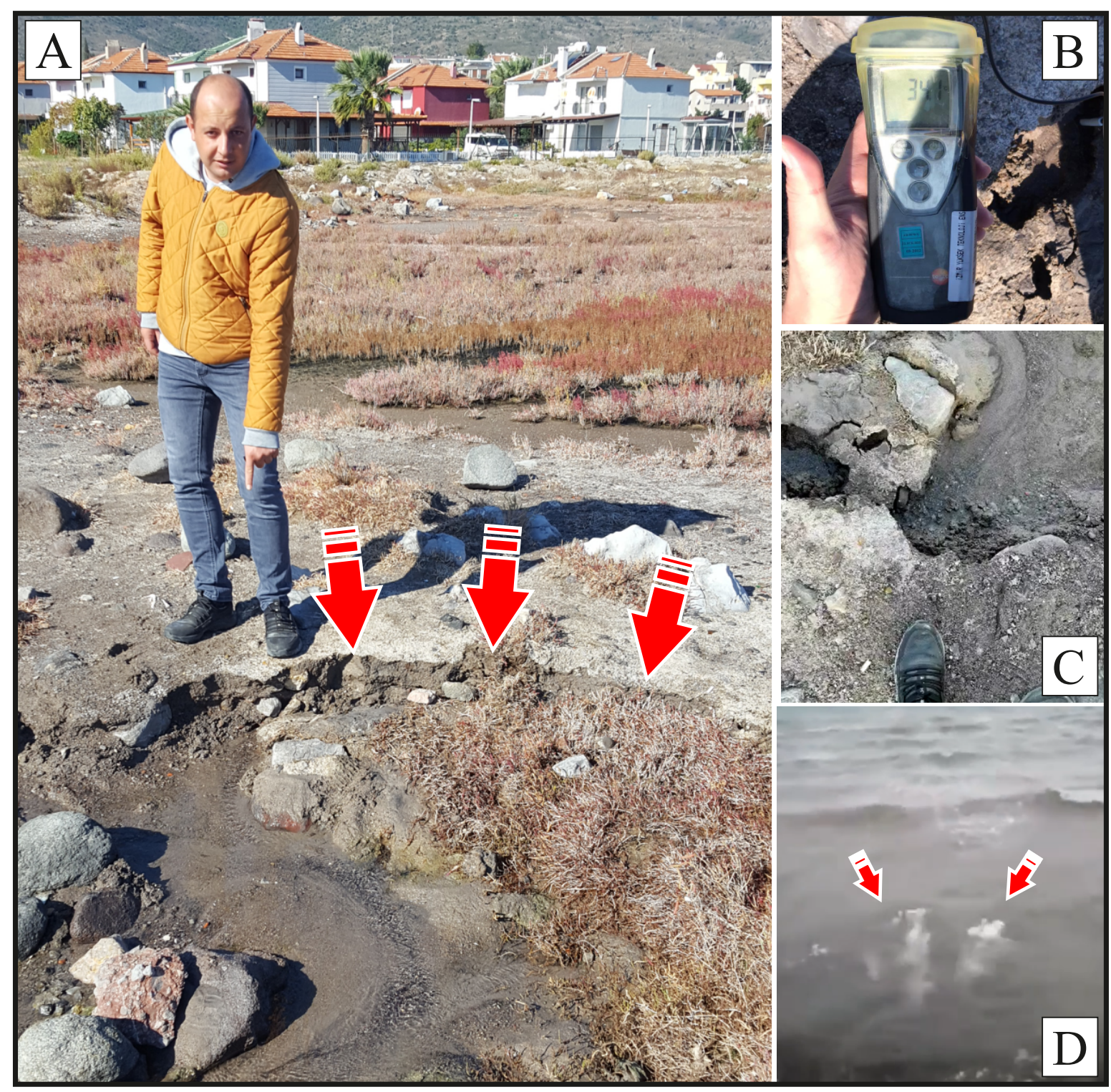

Figure 10. a) Hot water outflows observed during post-earthquake collapses on the shoreline b) water temperature measurements c) newly formed hot springs d) gas leakages in the sea before the November 20 earthquakes.

\section{Conclusion}

The Samos earthquake (October 30, 2020) caused a great loss of life and property damage in Bayraklı and Bornova. In Bayraklı region, 17 buildings collapsed and many buildings damaged due to alluvial soil properties and strong earthquake intensity induced ground motion. As can be seen from this earthquake, the ground-soil properties and the high groundwater level around Bayraklı can cause problems such as seismic wave amplification and liquefaction. If more observation stations are established in different geological units and different networks, higher quality and accurate groundwater level change signals will be obtained that can help to predict future earthquakes.
Different studies on earthquake-related changes in groundwaters attract much attention, especially in recent years. In these studies, it has been attempted to establish a connection between both groundwaters and earthquake characteristics. However, as it is known, there are many different controllers and very different impulse-response mechanisms in groundwater environments. In recent years, water scarcity, water pollution, floods, and earthquakes have made groundwater more important. In this context, detailed studies were initiated in the groundwaters and geothermal waters in İzmir province during the Samos earthquake and aftershocks. 


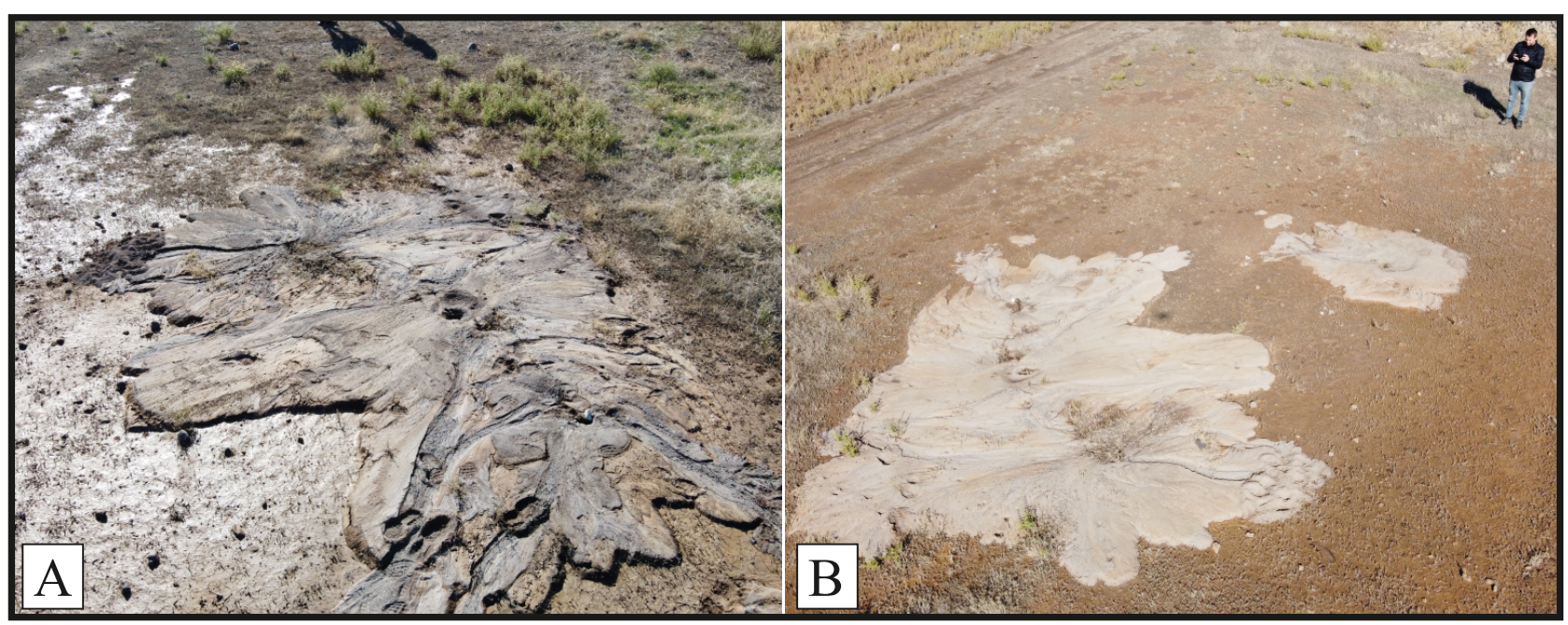

Figure 11. a) Sand volcanoes b) drone photo of the liquefaction site.

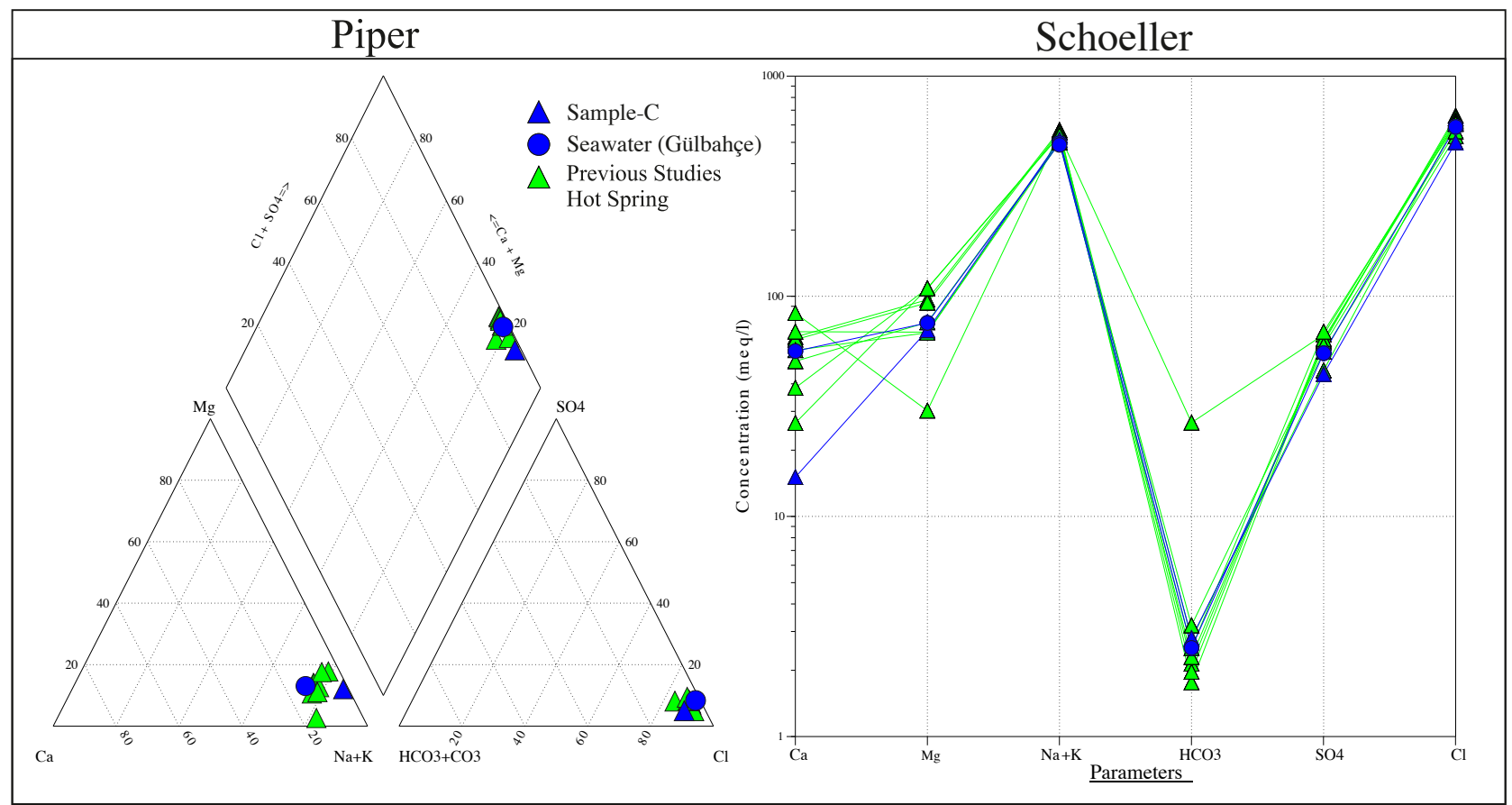

Figure 12. a) Piper diagram and b) Schoeller diagram of samples from Gülbahçe geothermal field.

Groundwater observations are among the most interesting studies. The association of these changes with seismic activity usually occurs with water level oscillations. The association of these changes with seismic activity usually occurs with abrupt water level changes and may be instantaneous as well as long-term value. Some water sources can be formed after an earthquake, while others may lose activity. With the beginning of monitoring processes of water sources that have gained importance in recent years, the researchers got the chance to follow instant changes such as earthquakes. In terms of seismicity, determining instantaneous level changes in advance is very important in earthquake prediction and resource protection.

In order to monitor the groundwater in Bayraklı Plain, 10 wells with a depth of $10 \mathrm{~m}$ were drilled 1 month before the Samos earthquake, and the monitoring process began. While temperature and water level changes were automatically measured at regular 1 -h intervals by divers placed in 5 of these wells, electrical conductivity measurements were made in one well. Especially, the water level rise steps observed in shallow wells are due to 


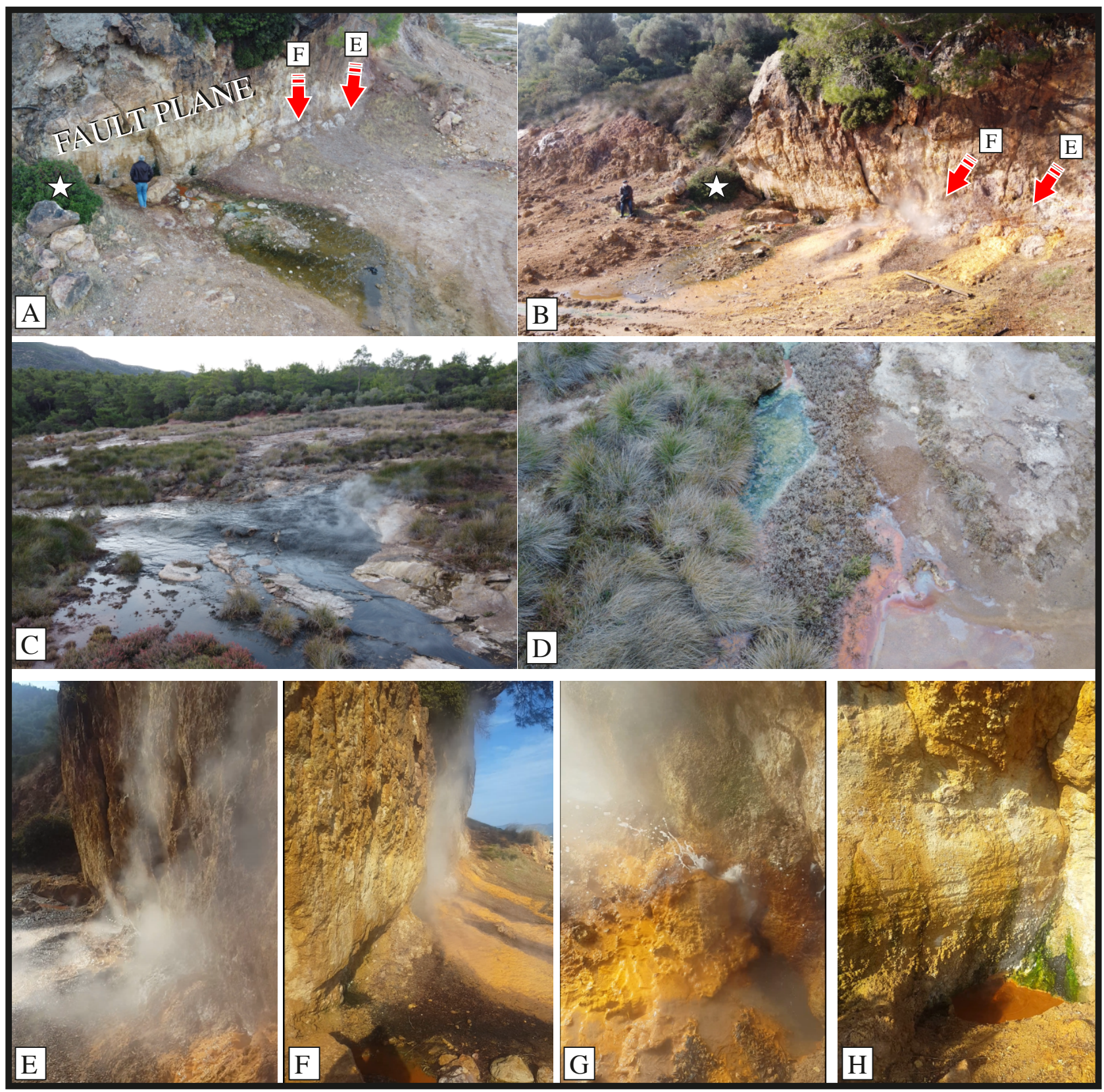

Figure 13. a) Fault plane view before geothermal springs are formed. b) Fault plane view after geothermal springs are formed, c) steam with muddy hot waters, d) hot water ponds (Sample-A region). e), f) and g) geothermal water and steam activity (Sample-B region), h) activity in front of the slickensided fault plane.

the compaction of the units during the earthquake. It is a significant finding that the instantaneous changes in the temperature, electrical conductivity, and water level in the shallow observation wells were determined at the time of and before the earthquake, even if they were centimeters in size.

Observations show that the dates of intense earthquakes with a magnitude greater than 3.5 and the time interval when water levels remained higher than pre-earthquake levels are almost the same, and both lasted 7-10 days. This is an important indication that seismic activity can keep water levels under control for a certain period, in addition to causing sudden increases in groundwater levels.

Furthermore, geothermal anomalies related to earthquakes in İzmir City and environs have been studied in detail, and significant anomalies were determined during and after the earthquake in the two important 


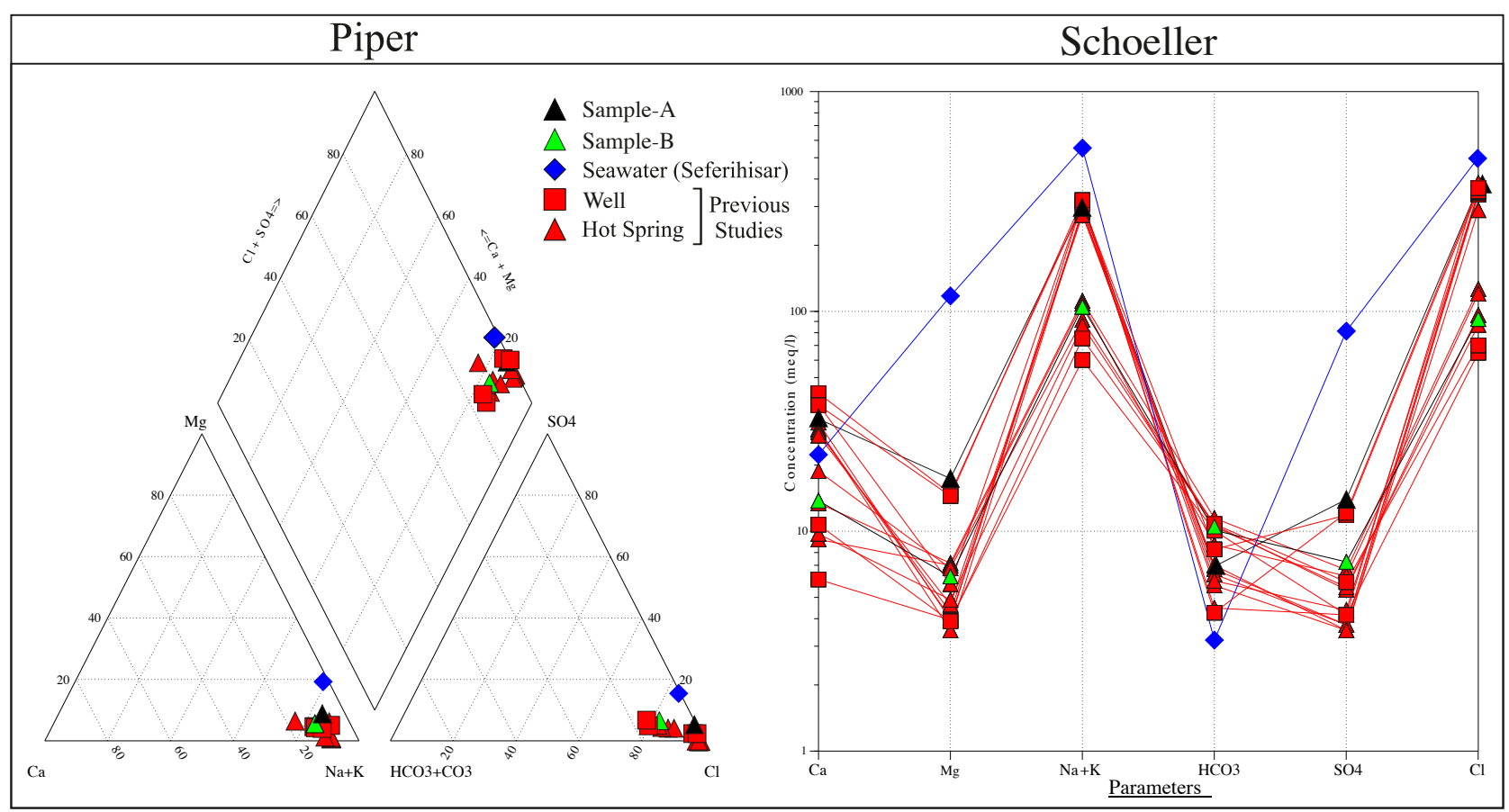

Figure 14. a) Piper diagram and b) Schoeller diagram of samples from Seferihisar geothermal field.

geothermal fields. Faults in the Seferihisar and Gülbahçe geothermal fields were affected by the Samos earthquake, and new geothermal springs were detected in these areas. Geothermal springs were formed at the seaside in the Gülbahçe field, and liquefaction was observed during the Samos earthquake. Also, essential quantities of gas have leaked before aftershocks that disturbed the marine floor of the Gülbahçe Bay.

Similar to the Seferihisar geothermal field, new geothermal waters and steam outlets were formed along the planes of the Tuzla Fault. During this earthquake, the situation that the geothermal waters did not mix with different aquifer flows was proved because the water

\section{References}

Akar TA (2012). Modelling of fluid flow in Seferihisar and Balçova geothermal fields and surrounding aquifers. PhD, Dokuz Eylül University Graduate School of Natural and Applied Science, Department of Geological Engineering, Department of Applied Geology, İzmir, Turkey (in Turkish).

Amoruso A, Crescentini L, Petitta M, Rusi S, Tallini M (2011). Impact of the April 62009 L'Aquila earthquake on groundwater flow in the Gran Sasso carbonate aquifer, Central Italy. Hydrological Processes 25 (11): 1754-1764. doi: 10.1002/hyp.7933

Baba A (2011). Hydrogeological and hydrogeochemical modeling of the geothermal resources in and around Gülbahçe. Scientific research project (IYTE BAP), IYTE21 (in Turkish). chemistry of the existing and newly emerged geothermal waters remained relatively the same character with minor differences. However, the temperature and flow rate increases, especially in geothermal waters after the Samos earthquake, are quite remarkable. In addition, the formation of new geothermal springs on known fault segments is a situation that should be carefully monitored in the long term.

\section{Acknowledgments}

The authors would like to thank anonymous reviewers for their constructive comments, insightful suggestions, and careful reading of the manuscript.

Baba A (2013). Gülbahçe Geothermal Resource Development Project. İzmir Development Agency Project (IZZKA), TR31/12/ DFD01/0015 (in Turkish).

Baba A, Yazdani H (2017). Effect of urbanization on groundwater resources of İzmir City. In: 4th International Water Congress, 2-4 November 2017; İzmir-Turkey.

Barberio MD, Barbieri M, Billi A, Doglioni C, Petitta M (2017). Hydrogeochemical changes before and during the 2016 Amatrice-Norcia seismic sequence (Central Italy). Scientific Reports 7 (1): 11735. doi: 10.1038/s41598-017-11990-8

Bozkurt E (2001). Neotectonics of Turkey - a synthesis. Geodinamica Acta 14: 3-30. 
Bredehoeft JD (1967). Response of well-aquifer systems to Earth tides. Journal of Geophysical Research 72: 3075-3087.

Brodsky EE, Roeloffs E, Woodcock E, Gall I, Manga M, (2003). A mechanism for sustained groundwater pressure changes induced by distant earthquakes. Journal of Geophysical Research 108: 2390. doi: 10.1029/2002JB002321

Bulut M (2013). A new medium to high enthalpy geothermal field in Aegean region (Akyar Menderes- Seferihisar-İzmir, Western Anatolia, Turkey. Bulletin of MTA 147: 153-167.

Charmoille A, Fabbri O, Mudry J, Guglielmi Y, Bertrand C (2005). Post-seismic permeability change in a shallow fractured aquifer following a ML 5.1 earthquake (Fourbanne karst aquifer, Jura outermost thrust unit, eastern France). Geophysical Research Letters 32 (L18406). doi: 10.1029/2005GL023859

Chatzipetros A, Kiratzi A, Sboras S, Zouros N, Pavlides S (2013). Active faulting in the north-eastern Aegean Sea Islands. Tectonophysics 597-598: 106-122.

Chen C, Wang C, Wen S, Yeh T, Lin C et al. (2013). Anomalous frequency characteristics of groundwater level before major earthquakes in Taiwan. Hydrology and Earth System Sciences 17 (5): 1693-1703.

Chia Y, Wang YS, Chiu JJ, Liu CW (2001). Changes of groundwater level due to the 1999 Chi-Chi earthquake in the Choshui River Alluvial Fan in Taiwan. Bulletin of the Seismological Society of America 91: 1062-1068.

Chiodini G, Cardellini C, Amato A, Boschi E, Caliro S et al. (2004). Carbon dioxide Earth degassing and seismogenesis in central and southern Italy. Geophysical Research Letters 31 (L07615). doi: 10.1029/2004GL019480

Ciarletti M, Plastino W, Peresan A, Nisi S, Copia L et al. (2016). Uranium groundwater monitoring and seismic analysis: A case study of the Gran Sasso Hydrogeological Basin, Italy. Pure and Applied Geophysics 173 (4): 1079-1095. doi: 10.1007/s00024015-1152-4

Claesson L, Skelton A, Graham C, Dietl C, Mörth M et al. (2004). Hydrogeochemical changes before and after a major earthquake. Geology 32 (8): 641-644. doi: 10.1130/G20542.1

Cooper Jr HH, Bredehoeft JD, Papadopulos IS, Bennett RR (1965). The response of well-aquifer systems to seismic waves. Journal of Geophysical Research 70: 3915-3926.

Cotecchia V, Salvemini A, Ventrella NA (1990). Interpretazione degli abbassamenti territoriali indotti dal terremoto del 23 Novembre 1980 e correlazioni con i danni osservati su talune strutture ingegneristiche dell'Area epicentrale irpina. Rivista Italiana Di Geotecnica 24 (4): 145-158 (in Italian).

Emre Ö, Barka A (2000). Active faults between the Gediz graben and the Aegean Sea (İzmir region). In: Seismicity of Western Anatolia Symposium (BADSEM 2000), Proceedings Book; İzmir, Turkey. pp. 131-132.

Emre Ö, Özalp S, Doğan A, Özaksoy V, Yıldırım C et al. (2005). Active faults and earthquake potentials of İzmir. MTA Reports 107: 80 (in Turkish).
Emre Ö, Duman TY, Özalp S, Elmacı H, Olgun Ş et al. (2013). Active Fault Map of Turkey with an Explanatory Text, 1:1.250.000 scale. Ankara-Turkey: General Directorate of Mineral Research and Exploration, Special Publication Series-30.

Erdoğan B (1990). Stratigraphic features and tectonic evolution of the İzmir-Ankara Zone in the region between İzmir and Seferihisar. Turkish Petroleum Geologists Association (TPJD) Bulletin 2: 1-20 (in Turkish).

Eşder T, Şimşek Ş (1975). Geology of İzmir-Seferihisar Geothermal area, Western Anatolia of Turkey; Determination of reservoirs by means of gradient drilling. In: Second United Nations Symposium the Development and Use of geothermal resources; San Francisco, California, USA, 20-29 May 1975.

Eşder T (1990). The crust structure convection mechanism of geothermal fluids in Seferihisar Geothermal area. International Earth Sciences Colloquium on the Aegean Region; İzmir, Turkey 1: 135-147.

Falcone RA, Carucci V, Falgiani A, Manetta M, Parisse B et al. (2012). Changes on groundwater flow and hydrochemistry of the Gran Sasso carbonate aquifer after 2009 L'Aquila earthquake. Italian Journal of Geosciences 131 (3): 459-474. doi: 10.3301/ IJG.2011.34

Favara R, Italiano F, Martinelli G (2001). Earthquake-induced chemical changes in the thermal waters of the Umbria region during the 1997-1998 seismic swarm. Terra Nova 13 (3): 227233. doi: 10.1046/j.1365-3121.2001.00347.x

Galassi DM, Lombardo P, Fiasca B, Di Cioccio A, Di Lorenzo T et al. (2014). Earthquakes trigger the loss of groundwater biodiversity. Scientific Reports 4 (1): 6273. doi: 10.1038/ srep06273

Ganas A, Elias P, Briole P, Tsironi V, Valkaniotis S et al. (2020). Fault responsible for Samos earthquake identified. Temblor. doi: 10.32858/temblor.134.

Gejl RN, Rygaard M, Henriksen HJ, Rasmussen J, Bjerg PL (2019). Understanding the impacts of groundwater abstraction through long-term trends in water quality. Water Research 156: 241-251.

He A, Singh RP (2019). Groundwater level response to the Wenchuan earthquake of May 2008. Geomatics, Natural Hazards and Risk 10 (1): 336-352. doi: 10.1080/ 19475705.2018.1523236.

Hsu S (1998). Plan for a groundwater monitoring network in Taiwan. Hydrogeology Journal 6 (3): 405-415.

Igarashi G, Saeki S, Takahata N, Sumikawa K, Tasaka S et al. (1995). Groundwater radon anomaly before the Kobe earthquake in Japan. Science (New York, N.Y.) 269 (5220): 60-61. doi: $10.1126 /$ science. 269.5220 .60

Italiano F, Martinelli G, Rizzo A (2004). Geochemical evidence of seismogenic-induced anomalies in the dissolved gases of thermal waters: A case study of Umbria (Central Apennines, Italy) both during and after the 1997-1998 seismic swarm. Geochemistry, Geophysics, Geosystems 5 (Q11001). doi: 10.1029/2004GC000720 
İzmir Jeotermal A.Ş. (2008). Report on the geochemical evaluation of the Seferihisar geothermal field, İzmir, Turkey (in Turkish).

Jones A (1939). Ancient Smyrna-Cecil John Cadoux: Ancient Smyrna. A history of the city from the earliest times to 324 A.D. Pp. xlv-f-438; 9 plates 3 maps. Oxford: Blackwell, 1938. Cloth, 25s. The Classical Review 53 (1): 27-28. doi: 10.1017/ S0009840X00088417

Kaown D, Koh D, Kim H, Koh HJ, Kim J et al. (2019). Evaluating the responses of alluvial and bedrock aquifers to earthquakes (ML 5.1 and ML 5.8) using hydrological and environmental tracer data. Hydrogeology Journal 27 (6): 2011-2025.

Kaya MN (2019). Hydrogeochemical investigation of thermal and mineral waters of İzmir-Ilıkpınar. Master of Science, Department of Geological (Hydrogeological) Engineering, Hacettepe University (in Turkish).

Kim J, Lee J, Petitta M, Kim H, Kaown D et al. (2019). Groundwater system responses to the 2016 ML 5.8 Gyeongju earthquake, South Korea. Journal of Hydrology 576: 150-163.

Kitagawa Y, Koizumi N, Takahashi M, Matsumoto N, Sato T (2006). Changes in groundwater levels or pressures associated with the 2004 earthquake off the west coast of northern Sumatra (M 9.0). Earth, Planets and Space 58 (2): 173-179.

Koizumi N (2013). Earthquake prediction research based on observation of groundwater. Synthesiology 6: 27-37.

La Vigna F, Carucci V, Mariani I, Minelli L, Pascale F et al. (2012). Intermediate-field hydrogeological response induced by L'Aquila earthquake: The Acque Albule hydrothermal system (Central Italy). Italian Journal of Geosciences 131 (3): 475-485. doi.org: 10.3301/IJG.2012.05

Lee HA, Woo NC (2012). Influence of the M 9.0 Tohoku Earthquake on groundwater in Korea. Journal of Geosciences 16 (1): 1-6.

Lee S, Ha K, Hamm S, Ko K (2013). Groundwater responses to the 2011 Tohoku Earthquake on Jeju Island, Korea. Hydrological Processes 27 (8): 1147-1157.

Lee JM, Woo NC, Koh DC, Kim KY, Ko KS (2020). Assessing aquifer responses to earthquakes using temporal variations in groundwater monitoring data in alluvial and sedimentary bedrock aquifers. Geomatics, Natural Hazards and Risk 11 (1): 742-765. doi: 10.1080/19475705.2020.1751310

Liu CY, Chia Y, Chuang PY, Chiu YC, Tseng TL (2018). Impacts of hydrogeological characteristics on groundwater-level changes induced by earthquakes. Hydrogeology Journal 26 (2): 451465 .

Little KE, Hayashi M, Liang S (2016). Community-Based Groundwater Monitoring Network Using a Citizen-Science Approach. Groundwater 54 (3): 317-324.

Manga M, Wang CY (2007). Earthquake hydrology. In: Schubert G, (Editor). Treatise on Geophysics. Vol. 4. Amsterdam: Elsevier, pp. 293-320.

Manga M, Wang CY (2015). 4.12. Earthquake hydrology. In Treatise on geophysics (2nd). Oxford: Elsevier, pp. 305-328. doi: 10.1016/B978-0-444-53802-4.00082-8
Özgür N, Pala EA, Degirmenci S (2017). Hydrogeological, Hydrogeochemical and Isotope Geochemical Features of the Geothermal Waters in Seferihisar and Environs, Western Anatolia, Turkey. In: IOP Conference Series: Earth and Environmental Science, 95, 022039.

Pasvanoglu S, Canik B, Rosen MR (2004). Hydrogeology and possible effects of the Mw 7.4 Marmara Earthquake (August $17,1999)$ on the Spring Waters in the Orhangazi-Bursa Area, Turkey. Geological Society of India 63 (3): 313-322.

Pavlides S, Tsapanos T, Zouros N, Sboras S, Koravos G et al. (2009). Using Active Fault Data for Assessing Seismic Hazard: A Case Study from NE Aegean Sea, Greece. In: Earthquake Geotechnical Engineering Satellite Conference XVIIth International Conference on Soil Mechanics \& Geotechnical Engineering 2-3.10.2009; Alexandria, Egypt.

Petitta M, Primavera P, Tuccimei P, Aravena R (2011). Interaction between deep and shallow groundwater systems in areas affected by Quaternary tectonics (Central Italy): A geochemical and isotope approach. Environmental Earth Sciences 63 (1): 11-30. doi: 10.1007/s12665-010-0663-7

Petitta M, Mastrorillo L, Preziosi E, Banzato F, Barberio MD et al. (2018). Water-table and discharge changes associated with the 2016-2017 seismic sequence in central Italy: Hydrogeological data and a conceptual model for fractured carbonate aquifers. Hydrogeology Journal 26: 1009-1026. doi: 10.1007/s10040017-1717-7

Poitrasson F, Dundas SH, Toutain JP, Munoz M, Rigo A (1999). Earthquake-related elemental and isotopic lead anomaly in a spring water. Earth and Planetary Science Letters 169 (3-4): 269-276. doi: 10.1016/S0012-821X(99)00085-0

Reddy DV, Nagabhushanam P, Sukhija BS (2011). Earthquake (M 5.1) induced hydrogeochemical and $\delta 180$ changes: Validation of aquifer breaching-Mixing model in Koyna, India. Geophysical Journal International 184 (1): 359-370. doi: 10.1111/j.1365-246X.2010.04838.x

Roeloffs EA (1988). Hydrologic precursors to earthquakes: a review. Pure and Applied Geophysics 126: 177-206.

Roeloffs EA, Nelms DL, Sheets A, Cunningham WL, Kozar M et al. (2011). Groundwater-level changes caused by strain and seismic shaking from the August 23, $2011 \mathrm{Mw} 5.8$ Virginia earthquake. In: 2011 Fall Meeting, AGU, San Francisco, California, 5-9 Dec.

Rojstaczer S, Wolf S (1992). Permeability changes associated with large earthquakes: an example from Loma Prieta, California, 10/17/89 Earthquake. Geology 20: 211-214.

Rosen MR, Binda G, Archer C, Pozzi A, Michetti AM et al. (2018). Mechanisms of earthquake-induced chemical and fluid transport to carbonate groundwater springs after earthquakes. Water Resources Research 54: 5225-5244. doi: 10.1029/2017WR022097

Rutter HK, Cox SC, Ward NFD, Weir JJ (2016). Aquifer permeability change caused by a nearfield earthquake, Canterbury, New Zealand. Water Resources Research 52 (11): 8861-8878. 
Senthilkumar M, Gnanasundar D, Mohapatra B, Jain A, Nagar A et al. (2020). Earthquake prediction from high-frequency groundwater level data: A case study from Gujarat, India. HydroResearch 3: 118-123.

Shi Z, Wang G (2014). Hydrological response to multiple large distant earthquakes in the Mile well, China. Journal of Geophysical Research: Earth Surface 119 (11): 2448-2459.

Shi Z, Wang G, Manga M, Wang Y (2015). Continental-scale waterlevel response to a large earthquake. Geofluids 15 (1-2): 310320 .

Shih DS (2018). Storage in confined aquifer: spectral analysis of groundwater in responses to Earth tides and barometric effect. Hydrological Processes 32 (12): 1927-1935.

Skelton A, Claesson L, Chakrapani G, Mahanta C, Routh J et al. (2008). Coupling between seismic activity and hydrogeochemistry at the Shillong Plateau, Northeastern India. Pure Applied Geophysics 165 (1): 45-61. doi: 10.1007/s00024-007-0288-2

Skelton A, Andrén M, Kristmannsdóttir H, Stockmann G, Mörth $\mathrm{CM}$ et al. (2014). Changes in groundwater chemistry before two consecutive earthquakes in Iceland. Nature Geoscience 7 (10): 752-756. doi:10.1038/ngeo2250

Sneed M, Galloway DL, Cunningham WL (2003). EarthquakesRattling the Earth's Plumbing System. Fact Sheet: 096-03. doi: 10.3133/fs09603.

Sun X, Xiang Y, Shi Z, Hu X, Zhang H (2019). Sensitivity of the response of well-aquifer systems to different periodic loadings: A comparison of two wells in Huize, China. Journal of Hydrology 572: 121-130.

Sözbilir H, Sümer Ö, Uzel B, Ersoy Y, Erkül F et al. (2009). 17-20 October 2005-Seismic geomorphology of the Sığacık Bay (İzmir) earthquakes and their relationship with the stress areas in the region, Western Anatolia. Geology Bulletin of Turkey 51 (2): 217-238 (in Turkish).

Sözbilir H, Softa M, Eski S, Tepe Ç, Akgün M et al. (2020). Dokuz Eylül University Earthquake Research and Application Center (DAUM), 30 October 2020 Samos (Samos) Earthquake (MW 6.9) Assessment Report, November 2020 (in Turkish).

Tarcan G (2001). Hydrogeology and Hydrogeochemistry of the Gülbahçe Bay Hydrothermal Karst System, İzmir, Turkey. In: Proceedings of the 6th International Symposium and Field Seminar on "Present State and Future Trends of Karst Studies" 17-26 Sept.2000; Marmaris-Turkey. Günay, Ford, Johnson \& Johnson (Editors), International Hydrological ProgrammeUNESCO, pp. 515-524.
Uzel B, Sözbilir H (2008). A first record of strike-slip basin in western Anatolia and its tectonic implication: The Cumaovası basin as an example. Turkish Journal of Earth Sciences 17: 559-591.

Uzel B, Sözbilir H, Özkaymak Ç (2012). Neotectonic evolution of an actively growing superimposed Basin in Western Anatolia: The Inner Bay of İzmir, Turkey. Turkish Journal of Earth Sciences 21: 439-471.

Uzelli T, Baba A, Mungan GG, Dirik RK, Sözbilir H (2017). Conceptual model of the Gülbahçe geothermal system, Western Anatolia, Turkey: Based on structural and hydrogeochemical data. Geothermics 68: 67-85. doi: 10.1016/j. geothermics.2017.03.003.

Van Duijvenboodem W, Taat J, Gast L (1993). Groundwater quality monitoring in the Netherlands. In: Alley WM (Editor). Regional Groundwater Quality. New York (NY): Van Nostrand Reinhold, pp. 515-535.

Wang CY, Cheng LH, Chin CV, Yu SB (2001). Coseismic hydrologic response of an alluvial fan to the 1999 Chi-Chi earthquake, Taiwan. Geology 29 (9): 831-834.

Woith H, Wang R, Maiwald U, Pekdeger A, Zschau J (2013). On the origin of geochemical anomalies in groundwaters induced by the Adana 1998 earthquake. Chemical Geology 339: 177-186. doi: 10.1016/j.chemgeo.2012.10.012

Worden CB, Gerstenberger MC, Rhoades DA, Wald DJ (2012). Probabilistic relationships between ground-motion parameters and modified Mercalli intensity in California. Bulletin of the Seismological Society of America 102: 204-221.

Yan R, Wang G, Shi Z (2016). Sensitivity of hydraulic properties to dynamic strain within a fault damage zone. Journal of Hydrology 543: 721-728.

Yun S, Hamm S, Cheong J, Lee C, Seo W et al. (2019). Analyzing groundwater level anomalies in a fault zone in Korea caused by local and offshore earthquakes. Geosciences Journal 23 (1): 137-148. 